\title{
The Historical Recovery of the Human Person as Subject of the Law Of Nations
}

\author{
Antônio Augusto Cançado Trindade
}

\section{Introduction: the inter-generational dialogue}

It is a source of satisfaction to me to return to the University of Cambridge after so many years, upon the initiative of its young scholars in statu pupillaris, and to associate myself with this Conference on the occasion of the launching of their Cambridge Journal of International and Comparative Law. I have always practiced and greatly value this inter-generational dialogue, and am deeply touched by the decision of my young colleagues of the new generations to open a space in their event for the presentation of the ideas I have laid down in my last book, The Access of Individuals to International Justice $]^{1}$ within the framework of the general theme of this 2012 Conference, "Agents of Change: The Individual as a Participant in the Legal Process".

May I at first ponder to my young colleagues assembled in this Conference that your condition in statu pupillaris is a privileged one, as the search for knowledge and justice never ends, and you have the time, which may seem to you to pass on slowly, in your favour. But beware, as the passing of time will in due course deprive you of this graceful condition of being in statu pupillaris. We, academic veterans, who have lost that condition a long time ago, greatly miss it, as we now realize that, in many respects, experience withdraws to a greater

Ph.D. (Cambridge-Yorke Prize) in International Law; Judge of the International Court of Justice; Former President of the Inter-American Court of Human Rights; Emeritus Professor of International Law at the University of Brasília, Brazil; Honorary Professor at the University of Utrecht; Doctor Honoris Causa at distinct Universities in Latin America; Member of the Institut de Droit International, and of the Curatorium of The Hague Academy of International Law.

1 Oxford University Press, 2011. 
extent than it gives. Moreover, the more knowledge we achieve to obtain, we realize that there is considerably more to learn.

Yet, we are bound to live within the shortness of our lifetime, which is never sufficient to learn as much as we wanted. Time seems to pass faster and faster, and we try in vain to slow it down, but the truth is that it is we who get slower and slower. To be alive is already a grace, and to be young, in statu puppilaris, is a privilege, if not a glory! May I thank very much the distinguished young colleagues of the new generations for the honour of the invitation to come back to Cambridge after a long time, which gives me the occasion of sharing some personal reflections with all present herein, in this colourful spring morning of 19 May 2012.

The topic of this Conference is indeed one of great relevance; it encompasses many aspects, of substantive and procedural law. Years ago I chose it for my research undertaken here in Cambridge, as much as the topic chose me. We indeed identify ourselves with the topic of our research, which accompanies us throughout our academic lifetime. Out of this identification with each other (the subject who searches knowledge, and the object of the knowledge sought), some insights keep on emerging. I shall be pleased to condense, in sequence, some of those insights, and to share them with all present in this Conference.

\section{The Legacy of the Individual's Subjectivity in the Emerging Law of Nations}

May I begin by pointing out that I have never been convinced by the heralds of conventional wisdom in spotting a historical moment, agreed upon, for the "beginning" of international law, "as we know it today": to me, international law, as we know it today, does not go back only to the ninetheenth century, as some authors would try to make one believe, but goes much further back in time, keeping in mind its conceptual framework and the endeavours, along centuries, to fulfil the aspirations of the whole of human kind. To start with, one should not forget, in our times, the considerable importance attributed to the condition of individuals in the law of nations (the droit des gens) by the so-called founding fathers of our discipline.

Their thinking had considerable importance and influence in their epoch; it was not exclusively state-centred, and projected itself in time. Its influence was

2 A A Cançado Trindade, The Application of the Rule of Exhaustion of Local Remedies in International Law (Cambridge University Press, 1983). 
understandable, given the necessity of systematization of the matter ${ }^{3}$ Even in our day it is necessary to keep its legacy in mind. Thus, along the sixteenth century, it may be recalled, the conception of Francisco de Vitoria (author of the renowned Relecciones Teológicas , 1538-1539) flourished, whereby the law of nations regulates an international community (totus orbis) constituted of human beings organized socially in States and coextensive with humanity itself $\left.\right|^{4}$

Furthermore, in his De Lege, Vitoria sustained the necessity of every law to pursue, above all, the common good; and he added that natural law is found not in the "will", but rather in right reason (recta ratio) ${ }^{5}$ In his understanding, the reparation of breaches of (human) rights reflects an international necessity fulfilled by the law of nations, with the same principles of justice applying both to States and to individuals and peoples who form them ${ }^{6}$ Over more than four and a half centuries later, his message retains a remarkable topicality.

On his turn, Alberico Gentili (author of De Jure Belli, 1598) sustained, by the end of the sixteenth century, that Law governs the relationships between the members of the universal societas gentium 7 In his De Jure Belli Libri Tres (1612), Gentili held that the law of nations was "established among all human beings", being observed by all mankind 8 In the seventeenth century, in the outlook advanced by the learned scholar Francisco Suárez (author of the treaty De Legibus ac Deo Legislatore, 1612), the law of nations discloses the unity and universality of humankind, and regulates the States in their relations as

3 For accounts of the formation of classic doctrine, cf., inter alia, L Le Fur, 'La théorie du droit naturel depuis le XVIIe. siècle et la doctrine moderne' (1927) 18 Recueil des Cours de l'Académie de Droit International de La Haye [RCADI] 259, at 297-399; P Guggenheim, Traité de droit international public, (Georg, 1967) vol. I, at 13-32; A Verdross, Derecho Internacional Público (Aguilar, 1969), at 47-62; C de Visscher, Théories et réalités en Droit international public (Pédone, 1970), at 18-32; A A Cançado Trindade, Princípios do Direito Internacional Contemporâneo (University of Brasília, 1981), at 20-1.

4 Cf. F de Vitoria, 'De Indis-Relectio Prior (1538-1539),' in T Urdanoz (ed), Obras de Francisco de Vitoria - Relecciones Teológicas (BAC, 1960), at 675.

5 F de Vitoria, La Ley (De Lege-Commentarium in Primam Secundae) (Tecnos, 1995), at 5, 23, 77.

6 J Brown Scott, The Spanish Origin of International Law-Francisco de Vitoria and his Law of Nations (Clarendon Press/H Milford-Carnegie Endowment for International Peace, 1934), at 282-283, 140, 150, 163-165, 172; A A Cançado Trindade, 'Co-existence and Co-ordination of Mechanisms of International Protection of Human Rights (At Global and Regional Levels)' (1987) 202 RCADI 9, at 411; A A. Cançado Trindade, 'Totus Orbis: A Visão Universalista e Pluralista do Jus Gentium: Sentido e Atualidade da Obra de Francisco de Vitoria' (2008) 24 Revista da Academia Brasileira de Letras Jurídicas 197, at n. 32.

7 A Gómez Robledo, infra n. 10, at 48-55.

8 A Gentili, De Jure Belli Libri Tres (1612) (Clarendon Press/H Milford-Carnegie Endowment for International Peace, 1933), vol. II, at 8. 
members of the universal society!?

It was, however, the other scholar, of Salamanca, Francisco de Vitoria, who gave a pioneering and decisive contribution to the notion of the prevalence of the rule of law: it was he who sustained, with rare lucidity, in his Relecciones Teologicas (1538-1539), that the legal order obliges everyone-those who are ruled as well as those who rule-and, in this same line of thinking, the international community (totus orbis) has primacy over the free will of each individual State ${ }^{10}$ In our days, it may be pointed out, the topic of the "the rule of law at the national and international levels" appears-since 2006-in the agenda of the UN General Assembly.

Shortly after Vitoria, Gentili and Suárez, the conception elaborated by Hugo Grotius (De Jure Belli ac Pacis, 1625), always attentive to the role of civil society, sustained that societas gentium comprises the whole of humankind, and the international community cannot pretend to base itself on the voluntas of each state individually; to Grotius, the state is not an end in itself, but a means to secure the social order in conformity with human reason, so as to "improve" the common society which encompasses the whole of humankind ${ }^{11}$ Human beings-occupying a central position in international relations-have rights vis-à-vis the sovereign state, which cannot demand obedience of their citizens in an absolute way (the imperative of the common good), as the so-called raison $d^{\prime}$ État has its limits, and cannot prescind from law ${ }^{12}$

In the thinking of $\mathrm{H}$ Grotius, every legal norm-of domestic or international law-creates rights and duties to the persons they are addressed; according to his legacy $\left.\right|^{13}$ the international community cannot pretend to be based on the voluntas of each State individually. Given the historical necessity to regulate the relations of the emerging States, Grotius sustained that such relations were ruled by legal norms, and not by the "raison d'Etat", which is incompatible with the existence itself of the international community: this latter cannot prescind from the law

9 Cf. Association Internationale Vitoria-Suarez, Vitoria et Suarez-Contribution des Théologiens au Droit International Moderne (Pédone, 1939), at 169-170.

10 Cf. F de Vitoria, Relecciones-del Estado, de los Indios, y del Derecho de la Guerra (Porrúa, 1985), at 1-101; A Gómez Robledo, Fundadores del Derecho Internacional (UNAM, 1989), at 30-9.

11 P P Remec, The Position of the Individual in International Law according to Grotius and Vattel (Nijhoff, 1960), at 216 and 203.

12 Ibid., at 219-20, 217.

13 Ibid., at 243, 221.

14 Cf. H Lauterpacht, 'The Grotian Tradition in International Law' (1946) 23 British Year Book of International Law 1. 
In the Grotian legacy, human beings and their well-being occupy a central position in the system of international relations; accordingly, the standards of justice apply vis-à-vis States as well as individuals..$^{15}$ In this line of reasoning, in the eighteenth century, Samuel Pufendorf (author of De Jure Naturae et Gentium, 1672) sustained as well the subjection of the legislator to human reason, while Christian Wolff (Jus Gentium Methodo Scientifica Pertractatum, 1749), pondered that, just as individuals ought to-in their association in the State-promote the common good, the state on its turn has the correlative duty to seek its perfection 16

\section{The Exclusion of the Individual from the International Legal Order by the Distortions of Legal Positivism}

The subsequent personification of the all-powerful State, inspired mainly in the philosophy of law of Hegel, had a harmful influence in the evolution of international law by the end of the nineteenth century and in the first decades of the twentieth century. Regrettably, the vision and thinking of the so-called "founding fathers" of international law (notably the writings of the Spanish theologians and of Grotius), which conceived it as conforming a truly universal ${ }^{17}$ system, came to be replaced by the emergence of legal positivism, which personified the State, endowing it with its own "will", reducing the rights of human beings to those which were "conceded" by the state. The consent or will of the States became, according to voluntarist positivism, the predominant criterion in international law, denying ius standi to individuals, to the human beings. This rendered difficult the understanding of the international community, weakening international law itself, reducing it

15 H Lauterpacht, 'The Law of Nations, the Law of Nature and the Rights of Man' (1943) 29 Transactions of the Grotius Society 1, at 7, 21-31.

16 C Wolff beheld nation-states as members of a civitas maxima, a concept which E de Vattel (author of Le Droit des Gens, 1758), later on, invoking the necessity of realism, intended to replace by a society of nations (a less advanced conception); cf. F S Ruddy, International Law in the Enlightenment-The Background of Emmerich de Vattel's Le Droit des Gens (Oceana, 1975), at 95; for a criticism to this step backwards (incapable of providing the foundation of the principle of obligation in international law), cf. J L Brierly, The Law of Nations (Clarendon Press, 1963), at 38-40.

17 C W Jenks, The Common Law of Mankind (Stevens, 1958), at 66-9; cf. R J Dupuy, La communauté internationale entre le mythe et l'histoire (Economica/UNESCO, 1986), at 164-5. 
to a strictly inter-State law, no longer above but between sovereign States ${ }^{18}$ This doctrinal trend resisted as much as it could to the ideal of the emancipation of the human being from the absolute control of the State, and to the recognition of the individual as subject of international law. The disastrous consequences of this distortion are widely known.

Yet, the individual's submission to the "will" of the State was never convincing to all, and it soon became openly challenged by the more lucid doctrine. The idea of absolute state sovereignty, which led to the irresponsibility and the alleged omnipotence of the state, not impeding the successive atrocities committed by it (or in its name) against human beings, appeared with the passing of time entirely unfounded. Against the reactionary dogmas of legal positivism stood, among others, Jean Spiropoulos, in a thoughtful monograph titled L'individu en Droit international, published in Paris in $1928{ }^{19}$ contrary to what ensued from the Hegelian doctrine, he pondered, the state is not a supreme ideal subjected only to its own will, is not an end in itself, but rather a means of the realization of the aspirations and vital necessities of the individuals, it thus being necessary to protect the human person against the harm to her rights by her own State ${ }^{20}$

Furthermore, in the past, positivists ascribed a far too great importance to the method of observation (neglected by other currents of thought), in contrast, however, with their total incapacity to present guidelines of analysis, and above all guiding general principles ${ }^{21}$ At the normative level, positivism appeared subservient to the established legal order, and validated the abuses perpetrated in its name. But already in the mid-twentieth century, the more lucid doctrine of the law of nations moved definitively away from the Hegelian and neo-Hegelian formulation of the state as the final repository of the freedom and responsibility of the individuals who composed it, and which in it integrated themselves entirely ${ }^{22}$

The old and sterile polemics, between monists and dualists, erected upon false premises, not surprisingly failed to contribute to the doctrinal endeavours on behalf of the emancipation of the human being vis-à-vis his own state. In effect, what both dualists and monists did, in this particular, was to

18 P P Remec, supra n. 11, at 36-37.

19 J Spiropoulos, L'individu en Droit international (LGDJ, 1928), at 66, 33, and cf. at 19.

20 Ibid., at 55; an evolution to this effect, he added, would bring us closer to the ideal of civitas maxima.

21 Cf. L Le Fur, supra n. 3, at 263.

22 W Friedmann, The Changing Structure of International Law (Stevens, 1964), at 247; E Weil, Hegel et l'État [1950] (J Vrin, 1974), at 11, 24, 44-5, 53-6, 59, 62, 100, 103. 
personify the state as subject of international law 23 Monists discarded all anthropomorphism, asserting the international subjectivity of the state by an analysis of the juridical person, ${ }^{24}$ and dualists-like Triepel and Anzilotti-did not restrain themselves in their excesses of characterization of the states as sole subjects of international law ${ }^{25}$ In effect, a whole doctrinal trend, of traditional positivism, formed, besides Triepel and Anzilotti, also by Strupp, Kaufmann, Redslob, among others, came to sustain that only the states were subjects of public international law. The same posture was adopted by the old Soviet doctrine of international law, with emphasis on the so-called inter-state peaceful coexistence 26

Against this vision an opposing doctrinal trend emerged, as from the publication, in 1901, of the book by Léon Duguit L'État, le droit objectif et la loi positive, formed by G Jèze, $\mathrm{H}$ Krabbe, $\mathrm{N}$ Politis and G Scelle, among others, sustaining, a contrario sensu, that ultimately only the individuals, addressees of all juridical norms, were subjects of international law (cf. infra). The idea of absolute state sovereignty, which led to the irresponsibility and the assumed omnipotence of the state, not impeding the successive atrocities perpetrated by this latter against the human beings, proved to be, with the passing of time, entirely groundless. The State-it is nowadays recognized-is responsible for all its acts-both iure gestionis and iure imperii-as well as for all its omissions. Created by the human beings themselves, composed by them, for them it exists, for the realization of their common good. In case of violation of human rights, the direct access of the individual to the international jurisdiction is thus fully justified, in order to vindicate those rights, even against the state itself ${ }^{27}$

${ }^{23}$ Cf. C T Eustathiades, 'Les sujets du Droit international et la responsabilité internationalenouvelles tendances' (1983), 84 RCADI 405.

${ }^{24}$ Ibid., at 406.

25 For a criticism of the incapacity of the dualist thesis to explain the access of individuals to the international jurisdiction, cf. P Reuter, Quelques remarques sur la situation juridique des particuliers en Droit international public, in La technique et les principes du Droit public-Études en l'honneur de G. Scelle (LGDJ, 1950), vol. II, at 542-3, 551.

26 Cf., e.g., Y A Korovin, S B Krylov et al, International Law (Academy of Sciences of the USSR/Institute of State and Law, [s/d]), at 93-8, 15-18; G I Tunkin, Droit international public-problèmes théoriques (Pédone, 1965), at 19-34.

27 S Glaser, 'Les droits de l'homme à la lumière du droit international positif', in Mélanges offerts à H. Rolin-Problèmes de droit des gens (Pédone, 1964), at 117-118, and cf. at 105-106, 114-116. Hence the relevance of the compulsory jurisdiction of the organs of international protection of human rights; Ibid., at 118. 


\section{The Legal Personality of the Individual as a Response to a Necessity of the International Community}

The individual is indeed subject of both domestic and international law ${ }^{28}$ In fact, he has always remained in contact, directly or indirectly, with the international legal order. In the inter-war period, the experiments of the minorities 29 and mandates ${ }^{30}$ systems under the League of Nations, for example, bear witness thereof ${ }^{31}$ They were followed, in that regard, by the trusteeship system ${ }^{32}$ under the United Nations era, parallel to the development under this latter, along the years, of the multiple mechanisms - conventional and extra-conventionalof international protection of human rights. Those early experiments in the twentieth century were of relevance for subsequent developments in the international safeguard of the rights of the human person ${ }^{33}$

To that effect of evidencing and reasserting the constant contact of the individual with the international legal order, the considerable evolution in the

${ }^{28}$ On the historical evolution of the legal personality in the law of nations, cf. H Mosler, 'Réflexions sur la personnalité juridique en Droit international public', in Mélanges offerts à H. Rolin-Problèmes de droit des gens (Pédone, 1964), at 228-51; G Arangio-Ruiz, Diritto Internazionale e Personalità Giuridica (Coop. Libr. Univ., 1972); G Scelle, 'Some Reflections on Juridical Personality in International Law' in G A Lipsky (ed), Law and Politics in the World Community (University of California Press, 1953), at 49-58, 336; J A Barberis, 'Nouvelles questions concernant la personnalité juridique internationale' (1983) 179 RCADI 157.

29 Cf., e.g., P de Azcárate, League of Nations and National Minorities: An Experiment (Carnegie Endowment for International Peace, 1945), at 123-130; J Stone, International Guarantees of Minorities Rights (Oxford University Press, 1932), at 56; A N Mandelstam, 'La protection des minorités' (1923) 1 RCADI 363.

30 Cf., e.g., G Diena, 'Les mandats internationaux', (1924) 5 RCADI 246; N Bentwich, The Mandates System (Longmans, 1930), at 114; Q Wright, Mandates under the League of Nations (Chicago University Press, 1930), at 69.

31 C A Norgaard, The Position of the Individual in International Law (Munksgaard, 1962), at 109-131; A A Cançado Trindade, 'Exhaustion of Local Remedies in International Law Experiments Granting Procedural Status to Individuals in the First Half of the Twentieth Century', (1977) 24 Netherlands International Law Review/Nederlands Tijdschrift voor international Recht 373.

32 Cf., e.g., C E Toussaint, The Trusteeship System of the United Nations (Stevens, 1956), at 39, 47, 249-50; J Beauté, Le droit de pétition dans les territoires sous tutelle (LGDJ, 1962), at 48-136; G Vedovato, 'Les accords de tutelle', (1950) 76 RCADI 613.

33 Cf., e.g., C T Eustathiades, 'Une nouvelle expérience en Droit international-Les recours individuels à la Commission des droits de l'homme' in Grundprobleme des internationalen Rechts-Festschrift für J. Spiropoulos, (Schimmlebusch, 1957), at 111-37, esp. at 77, 121, n. 30. 
last decades not only of the international law of human rights but likewise of international humanitarian law, has contributed decisively. This latter likewise considers the protected persons not only as simple object of regulation that they establish, but rather as true subjects of international law ${ }^{34}$ This is what clearly ensues from the fact that the four Geneva Conventions plainly prohibit the states parties to derogate-by special agreements-from the rules enunciated in them and in particular to restrict the rights of the persons protected set forth in them ${ }^{35}$ In effect, the impact of the norms of the international law of human rights has, in turn, been having already for a long time repercussions in the corpus iuris and application of international humanitarian law.

Thus, international humanitarian law gradually freed itself from a purely inter-state obsolete outlook, giving an increasingly greater emphasis-in the light of the principle of humanity-to the protected persons and to the responsibility for the violation of their rights ${ }^{36}$ Thus, in distinct contexts, the legal personality of individuals was reckoned in response to the needs of protection, and, ultimately, as a response to a necessity of the international community itself.

\section{The Individual's Presence and Participation in the International Legal Order}

The attempts of the past to deny to individuals the condition of subjects of international law, such as denying them some of the capacities which states have (such as, e.g., that of treaty-making), are definitively devoid of any meaning. Nor at the domestic law level do all individuals participate, directly or indirectly, in the law-making process, but they do not thereby cease to be subjects of the law. That doctrinal trend, attempting to insist on such a rigid definition

${ }^{34}$ It is what ensues, e.g., from the position of the four Geneva Conventions on International Humanitarian Law of 1949, erected as from the rights of the protected persons (e.g., III Convention, articles 14 and 78; IV Convention, article 27).

35 I, II and III Geneva Conventions, article 6; and IV Geneva Convention, article 7. In fact, as early as in the passage from the nineteenth to the twentieth century, the first Conventions on international humanitarian law expressed concern for the fate of human beings in armed conflicts, thus recognizing the individual as direct beneficiary of the international conventional obligations.

36 On the historical roots of this development, cf. E W Petit de Gabriel, Las Exigencias de Humanidad en el Derecho Internacional Tradicional (1789-1939) (Tecnos, 2003), at 149, 171, 210. 
of international subjectivity, conditioning this latter to the very formation of international norms and compliance with them, simply does not sustain itself, not even at the level of domestic law, in which it is not required-it has never been-from all individuals to participate in the creation and application of the legal norms in order to be subjects (titulaires) of rights, and bearers of duties.

This unsustainable conception appears contaminated by an ominous ideological dogmatism, which had as the main consequence to alienate the individual from the international legal order. It is surprising, if not astonishing and regrettable, to see that conception repeated mechanically and ad nauseam by a doctrinal trend, apparently trying to make believe that the intermediary of the state, between the individuals and the international legal order, would be something inevitable and permanent. Nothing could be more fallacious. In the brief historical period in which that Statist conception prevailed, in the light-or, more precisely, in the darkness-of legal positivism, successive atrocities were committed against the human being, in a scale without precedents.

There is another point which passes unperceived to the heralds of the statist outlook of international law: in their myopia, proper of the dogmatisms, they seem not to perceive that the individuals have already began to participate effectively in the process of elaboration of norms of international law, which today appears much more complex than some decades ago. This phenomenon ensues from the democratization, which, in our days, also comes to encompass the international level[ ${ }^{37}$ This is illustrated, as already pointed out, by the growing presence and participation of entities of the civil society (NGOs and others), as verified in the travaux préparatoires of recent treaties as well as throughout the prolonged cycle of the great World Conferences of the United Nations during the decade of the nineties and the earlier years of last decade.

Today there is nothing intrinsic to international law that impedes or renders it impossible for non-state actors to enjoy international legal personality. No one in sane conscience would today dare to deny that the individuals effectively possess rights and obligations which emanate directly from international law, with which they find themselves, therefore, in direct contact. And it is perfectly possible to conceptualize-even with greater precision-as subject of international law any person or entity, titulaire of rights and bearer of obligations, which emanate directly from norms of international law. It is the case of the individuals, who thus have strengthened this direct contact-without

37 Cf., e.g., A A Cançado Trindade, 'Democracia y Derechos Humanos: Desarrollos Recientes, con Atención Especial al Continente Americano' in F Mayor (ed), Amicorum Liber-Solidarité, Égalité, Liberté-Livre d'Hommage offert au Directeur Général de l'UNESCO à l'occasion de son 60e. Anniversaire (Bruylant, 1995). 
intermediaries-with the international legal order. The international movement in favour of human rights, launched by the Universal Declaration of $\mathrm{Hu}-$ man Rights of 1948, came to disauthorize the aforementioned false analogies, and to overcome traditional distinctions (e.g., on the basis of nationality): subjects of law are all human beings as members of the universal society ${ }^{38}$

Moreover, individuals and non-governmental organizations (NGOs) assume nowadays an increasingly relevant role in the formation of opinio iuris communis ${ }^{39}$ NGOs have gained considerable visibility throughout the recent cycle of UN World Conferences (1992-2001), by their presence and lobbying in the Conferences themselves ${ }^{40}$ or by their articulation in their own forums parallel to such Conferences ${ }^{41}$ In recent years, they have been entitled to present on a regular basis their amici curiae before international tribunals such as the Inter-American and the European Courts of Human Rights, and the ad hoc International Criminal Tribunals for the Former Yugoslavia and for Rwanda.

In recent years, individuals and NGOs have effectively participated in the travaux préparatoires of certain international treaties, or influenced them ${ }^{42}$ as well as in the monitoring of their implementation. The growing performance,

38 R Cassin, 'L'homme, sujet de droit international et la protection des droits de l'homme dans la société universelle,' in La technique et les principes du Droit public-Études en l'honneur de G. Scelle (LGDJ, 1950), vol. I, at 81-82.

39 At the global level, article 71 of the UN Charter has served as basis to the advisory status of NGOs acting in the ambit of the UN, and resolution 1996/31, of 26 July 1996, of the UN Economic and Social Council (ECOSOC), regulates in detail the relations between the UN and NGOs with advisory status (providing the framework for accreditation of the latter). At the regional level, the Permanent Council of the Organization of American States (OAS) has issued directives (on 15 December 1999) governing the participation of NGOs and other entities of civil society in OAS activities; ever since they have appeared regularly before the Council and other OAS organs. And the European Convention on Recognition of the Legal Personality of International Non-Governmental Organizations (of 24 April 1986), on its turn, provides for the constitutive elements of the NGOs (article 1) and for the ratio legis of their legal personality and capacity (article 2).

40 The Rules of Procedure of the Preparatory Committee to the UN World Conference against Racism, Racial Discrimination, Xenophobia and Related Intolerance (Durban, 2001), e.g., contained a provision (rule 66) which regulated the participation of NGOs directly in its own work (as from May 2000).

${ }^{41}$ For my personal recollections of the World NGO Forum parallel to the UN II World Conference on Human Rights (Vienna, 1993), cf. A A Cançado Trindade, Tratado de Direito Internacional dos Direitos Humanos (S A Fabris, 2003), vol. I, at 220-31; and cf. also M. Nowak (ed), World Conference on Human Rights (Vienna, June 1993)-The Contribution of NGOs, Reports and Documents (Manzsche Verlags- und Universitätsbuchhandlung, 1994), at 1-231.

42 E.g., the 1984 UN Convention against Torture and its 2002 Optional Protocol; the 1989 UN Convention on the Rights of the Child; the 1991 Madrid Protocol (to the 1959 Antarctica Treaty) on Environmental Protection in the Antarctica; the 1997 Ottawa Convention on the 
at the international level, of NGOs and other entities of civil society has had an inevitable impact in the theory of the subjects of international law, contributing to render individuals not only direct beneficiaries (without intermediaries) of the international norms, but true subjects of international law, and to put an end to the purely inter-state anachronistic dimension of this latter; moreover, their activities have contributed to the prevalence of superior common values in the ambit of international law ${ }^{43}$ Individuals, NGOs and other entities of civil society come, thus, to act in the process of formation as well as in the application of international norms 44

In sum, the very process of formation and application of the norms of international law has ceased to be a monopoly of the states. In addition, individuals should also have the procedural capacity to vindicate their rights at the international level. It is by means of the consolidation of the full international procedural capacity of individuals that the international protection of human rights has become reality ${ }^{45}$ But even if, by the circumstances of life, certain individuals (e.g., children, the mentally ill, aged persons, among others) cannot fully exercise their capacity (e.g., in civil law), this does not mean that they cease to be titulaires of rights, opposable even to the state. Irrespective of the circumstances, the individual is subject iure suo of international law, as sustained by the more lucid doctrine, since the writings of the so-called founding fathers of the discipline ${ }^{46}$ Human rights were conceived as inherent to every human being, independently of any circumstances.

Prohibition of Anti-Personnel Mines and on Their Destruction; the 1998 Rome Statute of the International Criminal Court; and the 2005 UNESCO Convention on the Protection and Promotion of the Diversity of Cultural Expressions.

43 R Ranjeva, 'Les organisations non-gouvernementales et la mise-en-oeuvre du Droit international' (1997) 270 RCADI 9, at 22, 50, 67-8, 74, 101-2.

44 M Bettati and P-M Dupuy, Les O.N.G. et le Droit international (Economica, 1986), at 1, 16, 19-20, 252-61, 263-5.

45 Cf. A A Cançado Trindade, El Acceso Directo del Individuo a los Tribunales Internacionales de Derechos Humans (University of Deusto, 2001), at 17-96; A A Cançado Trindade, 'Vers la consolidation de la capacité juridique internationale des pétitionnaires dans le système interaméricain des droits de la personne' (2001), 14 Revue québécoise de Droit international 207, at $\mathrm{n} .2$.

46 P N Drost, Human Rights as Legal Rights (Sijthoff, 1965), at 226-7, and cf. at 215, 223. 


\section{The Rescue of the Individual as Subject of International Law}

Although the contemporary international scenario is entirely distinct from that of the epoch of the so-called founding fathers of international law (no one would deny it), who propounded a civitas maxima ruled by the law of nations, there is a recurrent human aspiration, transmitted from one generation to another, along the last centuries, to the effect of the construction of an international legal order applicable both to states (and international organizations) and to individuals, pursuant to certain universal standards of justice. Hence the importance which, in this new corpus iuris of protection, the international legal personality of the individual assumes, as subject of both domestic and international law.

The individual, as subject of international law in his own right, was certainly distinguishable from his own state, and a wrong done to him was a breach of classical ius gentium, as universal minimal law 47 The whole new corpus iuris of the international law of human rights has been constructed on the basis of the imperatives of protection and the superior interests of the human being, irrespectively of his link of nationality or of his political statute, or any other situation or circumstance. Hence the importance assumed, in this new law of protection, by the legal personality of the individual, as subject of both domestic and international law. The application and expansion of the international law of human rights, in turn, has repercussions, not surprisingly, and with a sensible impact, in the trends of contemporary public international law ${ }^{48}$

In fact, already in the first decades of the twentieth century one recognized the manifest inconveniences of the protection of the individuals by the intermediary of their respective states of nationality, that is, by the exercise of discretionary diplomatic protection, which rendered the complaining states at a time judges and parties. One started, as a consequence, to overcome such inconveniences, to nourish the idea of the direct access of the individuals to the international jurisdiction, under certain conditions, to vindicate their rights against States, a theme which came to be effectively considered by the Institut de Droit International in its sessions of 1927 and 1929.

47 C Parry, 'Some Considerations upon the Protection of Individuals in International Law', (1956) 90 RCADI 557, 686-8, 697-8.

48 Cf. A A Cançado Trindade, Tratado de Direito Internacional dos Direitos Humanos (S A Fabris, 2003), vol. I, at 33-50, and vol. II, at 23-194; A A Cançado Trindade, O Direito Internacional em um Mundo em Transformacao (Renovar, 2002), at 1048-1109; A A Cançado Trindade, El Derecho Internacional de los Derechos Humanos en el Siglo XXI (Editorial Jurídica de Chile, 2001), at 15-58, 375-427. 
In a monograph published in 1931, the Russian jurist André Mandelstam warned as to the necessity of the recognition of a juridical minimum-with the primacy of international law and of human rights over the state legal order-below which the international community should not allow the state to fall. In his vision, the horrible experience of our time demonstrated the urgency of the necessary acknowledgement of this juridical minimum, to put an end to the unlimited power of the state over the life and the freedom of its citizens, and to the complete impunity of the state in breach of the most sacred rights of the individual 49

In his celebrated Précis du Droit des Gens (1932-1934), Georges Scelle criticized the fiction of the contraposition of an inter-state society to a (national) society of individuals: one and the other-he pondered-are formed by individuals, subjects of domestic law and of international law, whether they are individuals moved by private interests, or else endowed with public functions (rulers and public officials) in charge of looking after the interests of national and international collectivities 50 Scelle then identified the movement of extension of the legal personality of individuals, by means of the emergence of the right of individual petition at the international level, which led him to conclude that: "Les individus sont à la fois sujets de droit des collectivités nationales et de la collectivité internationale globale: ils sont directement sujets de droit des gens" $[1]$

Still in the inter-war period, Albert de La Pradelle pondered that the droit des gens transcended inter-state relations, in regulating them to protect human beings (and to allow them to be masters of their own destiny), and to secure the compliance by States with their duties vis-à-vis the individuals under their respective jurisdictions. ${ }^{52}$ The strictly inter-state outlook is a particularly dangerous one; attentions ought to focus on the general principles of law, emanating from the juridical conscience, pursuant to jusnaturalist thinking, conforming a true "droit de l'humanite", so as to secure respect for the rights of the human person 53

\footnotetext{
49 A N Mandelstam, Les droits internationaux de l'homme (Internationales, 1931), at 95-6, 138, and cf. at 103.

50 G Scelle, Précis de Droit des Gens-Principes et systématique (Libr. Rec. Sirey, 1932), at 42-4.

$51 \mathrm{Ibid}$. at 48. Also singling out the importance of the attribution to individuals of remedies for the protection of their rights, cf. Lord McNair, Selected Papers and Bibliography (Sijthoff/Oceana, 1974), at 329, 249.

52 A de La Pradelle, Droit international public (cours sténographié) (Institut des Hautes Études Internationales/Centre Européen de la Dotation Carnegie, 1932-1933), at 49, 80-1, 244, 251, 263-6, 356.

${ }^{53}$ Ibid., at 33-4, 230, 257, 261, 264, 412-3.
} 
Also in the American continent, in the twentieth century, even before the adoption of the American and Universal Declarations of Human Rights of 1948, doctrinal manifestations flourished in favour of the international juridical personality of the individuals, such as those which are found, for example, in the writings of Alejandro Ãlvarez ${ }^{54}$ and Hildebrando Accioly ${ }^{55}$ Likewise, Levi Carneiro wrote, in this respect, that "no doctrinal obstacle subsists to the admission of individual claims to international justice. (...) The individual is increasingly of concern to international law", as "the State, created in the interest of the individual, cannot overcome this latter" "56 And Philip Jessup, in 1948, pondered that the old conception of State sovereignty was not consistent with the higher interests of the international community and the status of the individual as subject of international law ${ }^{57}$

In Europe, Hersch Lauterpacht, in a thoughtful book published in 1950, did not hesitate to assert that the individual is the final subject of all law, there being nothing inherent to international law impeding him to become subject of the law of nations and to become a party in proceedings before international tribunals ${ }^{58}$ On his turn, in another perspicacious essay, published also in 1950, Maurice Bourquin pondered that the growing concern of the international law of the epoch with the problems which affected directly the human being revealed the overcoming of the old exclusively inter-state vision of the international legal order ${ }^{59}$

In a book written shortly before his death, and published in 1954, Max

54 A Ãlvarez, La Reconstrucción del Derecho de Gentes-El Nuevo Orden y la Renovación Social (Nascimento, 1944), at 46-7, 457-463 and cf. at 81, 91, 499-500; A Ãlvarez, El Nuevo Derecho Internacional en Sus Relaciones con la Vida Actual de los Pueblos (Jurídica de Chile, 1962), at 49, 57, 77, 155-156, 163, 292, 304, 357.

55 H Accioly, Tratado de Direito Internacional Público (Imprensa Nacional, 1933), vol. I, at 71-75.

56 L Carneiro, O Direito Internacional e a Democracia (A. Coelho Branco Fo., 1945), at 121, 108, and cf. 113, 35, 43, 126, 181, 195.

57 P C Jessup, A Modern Law of Nations-An Introduction (MacMillan Co., 1948), at 41.

58 H Lauterpacht, International Law and Human Rights (Stevens, 1950), at 69, 61 and 51, and cf. at 70. Such recognition of the individual as subject of rights also at the international law level brings about a clear rejection of the old positivist dogmas, discredited and unsustainable, of the dualism of subjects in the domestic and international orders, and of the "will" of states as exclusive "source" of international law; cf. ibid., at 8-9. On the "natural right" of petition of individuals, exercised also in the general interest, cf. ibid., at 247-251, and cf. at 286-291, 337. And cf. also, in the same sense, H Lauterpacht, 'The Revision of the Statute of the International Court of Justice,' in E Lauterpacht (ed), International Law, Being the Collected Papers of Hersch Lauterpacht (Cambridge University Press, 2004), vol. V, at 164-6.

59 M Bourquin, 'L'humanisation du droit des gens', La technique et les principes du Droit public-Études en l'honneur de Georges Scelle (LGDJ, 1950), vol. I, at 21-54. 
Huber, in attesting the "devaluation" of the human person and the social "degradations" at the interior of the states, from 1914 until then, sustained a ius gentium, in the line of jusnaturalist thinking, centred on human beings and not on the states, recalling the ideal of the jusphilosophers of the civitas maxima gentium ${ }^{60}$ (cf. supra). Huber had in mind the correct application of international humanitarian law. A short while ago, at the International Court of Justice, in the case of the Jurisdictional Immunities of the State (Germany $v$ Italy, with Greece intervening, Judgment of 3 February 2012), in my recent and extensive Dissenting Opinion appended thereto, I had the occasion to rescue this doctrinal thinking (paras. 32-40), forgotten in our days, particularly the writings of de la Pradelle, Huber and Ãlvarez, singling out fundamental human values.

For his part, in his course delivered at the Hague Academy of International Law, three years later, in 1953, Constantin Eustathiades linked the international subjectivity of the individuals to the broad theme of the international responsibility (parallel to that of the states). As a reaction of the universal juridical conscience, the recognition of the rights and duties of the individual at the international level, and his capacity to act in order to defend his rights, are linked to his capacity to commit an international delict; international responsibility thus comprises, in his vision, both the protection of human rights as well as the punishment of war criminals (forming a whole) ${ }^{6}$ This development heralded the emancipation of the individual from the tutelage of his own State; thus, one cannot deny the individual's condition of subject of international law

The same conclusion was reached by Paul Guggenheim, in a course delivered also at the Hague Academy, one year earlier, in 1952: as the individual is subject of duties at the international law level, one cannot deny his international legal personality, recognized also in fact by customary international law itself ${ }^{63}$ Still in the mid-twentieth century, in the first years of

${ }^{60}$ M Huber, La pensée et laction de la Croix-Rouge (CICR, 1954), at 26, 247, 270, 286, 291-293, 304.

${ }^{61}$ C T Eustathiades, 'Les sujets du Droit international et la responsabilité internationaleNouvelles tendances', (1953) 84 RCADI 397, at 402, 412-413, 424, 586-589, 601, 612.

62 Ibid., 426-7, 547, 586-7, 608, 610-1. Although not endorsing the theory of Duguit and Scelle (of the individuals as the sole subjects of international law), regarded as expression of the sociological school of international law in France, Eustathiades recognized in it the great merit of reacting to the traditional doctrine which visualized states as the sole subjects of international law; the recognition of the international subjectivity of individuals, parallel to that of states, came to transform the structure of International Law and to foster the spirit of international solidarity; Ibid., at 604-10.

63 P Guggenheim, 'Les principes de Droit international public' (1952) 80 RCADI 116, and cf. at 
application of the European Convention on Human Rights, there was support for the view that the individuals had become titulaires of legitimate international interests, as, in international law, a process of emancipation of the individuals from the exclusive tutelage of the State agents had already started ${ }^{64}$ In the legal doctrine of that time the recognition of the expansion of the protection of individuals in the international legal order became evident ${ }^{65}$ In the lucid words of Röling, the overcoming of legal positivism was reassuring, as the individual, bearer of international rights and duties, was no longer at the mercy of his State, and: "[h] umanity of today instinctively turns to this natural law, for the function of law is to serve the well-being of man, whereas present positive international law tends to his destruction.66

This view was in keeping with the posture upheld by the Japanese jurist Kotaro Tanaka, in his Opinions in cases before the ICJ at The Hague in that epoch, that is, an international law transcending the limitations of legal positivism ${ }^{67}$ and thus capable of responding effectively to the needs and aspirations of the international community as a whole ${ }^{68}$ In the late 1960 s, the pressing need was pointed out of protecting internationally the human person both individually and in groups ${ }^{69}$ for unless such international protection was

$117-118$.

${ }^{64}$ G Sperduti, 'L'individu et le droit international', (1956) 90 RCADI 727, at 824, 821, 764. The juridical experience itself of the epoch contradicted categorically the unfounded theory according to which the individuals were simple objects of the international legal order, and destructed other prejudices of state positivism; Ibid., at 821-2; and cf. also G Sperduti, L'Individuo nel Diritto Internazionale (Giuffrè 1950), at 104-7.

${ }^{65}$ C Parry, 'Some Considerations upon the Protection of Individuals in International Law', (1956) 90 RCADI 722; B V A Röling, International Law in an Expanded World (Djambatan, 1960), at XXII, 1-2.

${ }^{66}$ B V A Röling, ibid., at 2.

67 Cf. Y Saito, 'Judge Tanaka, Natural Law and the Principle of Equality', in G Aldredsson and P Macalister-Smith (eds), The Living Law of Nations-Essays in Memory of A. Grahl-Madsen (N P Engel Publ., 1996), at 401-2, 405-8; K Tanaka wanted law to be wholly liberated from both the state (as asserted by Hegel and his followers) and from the nation (Völk, as asserted by Savigny and Puchta, and other jurists of the historical school); Ibid., at 402.

${ }^{68}$ Cf. V Gowlland-Debbas, 'Judicial Insights into Fundamental Values and Interests of the International Community', in A S Muller et al (eds), The International Court of Justice: Its Future Role after Fifty Years (Kluwer, 1997), at 344-6.

69 As acknowledged, e.g., by the 1994 Framework Convention for the Protection of National Minorities of the Council of Europe (in force as from February 1998). For earlier general studies, cf., e.g., P Thornberry, International Law and the Rights of Minorities (Clarendon Press, 1992), at 38-54; F Ermacora, 'The Protection of Minorities before the United Nations', (1983) 182 RCADI 257. Cf. also the 1989 ILO Convention concerning Indigenous and Tribal Peoples in Independent Countries (ILO Convention n. 169, in force as from 5 September 1991). 
secured to individuals and groups of them, the fate of the individual would be at the mercy of some Staatsrecht ${ }^{70}$ In an essay published in 1967, René Cassin, who had participated in the preparatory process of the elaboration of the Universal Declaration of Human Rights of $1948,^{17}$ stressed with eloquence the advance represented by the access of individuals to international instances of protection, secured by many human rights treaties:

If there still subsist on earth great zones where millions of men and women, resigned to their destiny, do not dare to utter the least complaint nor even to conceive that any remedy whatsoever is made possible, those territories diminish day after day. The awakening of conscience that an emancipation is possible, becomes increasingly more general. (...) The first condition of all justice, namely, the possibility of cornering the powerful so as to subject them to (...) public control, is nowadays fulfilled much more often than in the past. (...) The fact that the resignation without hope, that the wall of silence and that the absence of any remedy are in the process of reduction or disappearance, opens to moving humanity encouraging perspectives $(. . .)^{72}$

To Paul Reuter, individuals become subjects of international law when two basic conditions are fulfilled, namely, when they are titulaires of rights established directly by international law, which they can exercise, and are bearers of obligations sanctioned directly by international law ${ }^{73}$ A similar view was

Furthermore, endeavours undertaken in both the United Nations and the OAS, throughout the nineties, to reach the recognition of indigenous peoples' rights through their projected and respective Declarations, pursuant to certain basic principles (such as, e.g., that of equality and non-discrimination), have emanated from human conscience. Those endeavours, it has been suggested, recognize the debt that humankind owes to indigenous peoples, due to the historical misdeeds against them, and a corresponding sense of duty to undo the wrongs done to them; A Meijknecht, Towards International Personality: The Position of Minorities and Indigenous Peoples in International Law (Intersentia, 2001), at 228, 233.

70 J J Lador-Lederer, International Group Protection (Sijthoff, 1968), at 19.

71 As rapporteur of the Working Group of the United Nations Commission on Human Rights, entrusted with the preparation of the Draft Declaration (May 1947 to June 1948).

72 R Cassin, 'Vingt ans après la Déclaration Universelle', (1967) 8 Revue de la Commission Internationale de Juristes 9 , n. 2, at 9-10, and cf. at 11-7.

73 Thus, as from the moment when the individual is granted a remedy before an organ of international protection (access to international jurisdiction) and can thus initiate the procedure of protection, he becomes subject of international law; P Reuter, Droit international public (PUF, 1993), at 235, 238, and cf. at 106. 
upheld by Eduardo Jiménez de Aréchaga, to whom there is nothing inherent to the structure of the international legal order which impedes the recognition to the individuals of rights that emanate directly from international law, as well as international remedies for the protection of those rights ${ }^{74}$ Also in this line of reasoning, Barberis pondered in 1983 that, for individuals to be subjects of law, it is necessary that the legal order at issue attributes to them rights or obligations (as is the case of international law) 75

In fact, successive studies of instruments of international protection came to emphasize precisely the historical importance of the recognition of the international legal personality of individuals as complaining party before international organs ${ }^{76}$ In my own lectures delivered at the Hague Academy of International Law in 1987, I pondered that the continuous expansion of international law is also reflected in the multiple contemporary mechanisms of international protection of human rights, the operation of which cannot be dissociated from the new values acknowledged by the international community 77 At last individuals were enabled to exercise rights emanating directly from International Law (droit des gens). And I added:

In this connection, the insight and conception of Vitoria developed in his manuscripts of 1532 (made public in 1538-1539), can be properly recalled in 1987 , four-and-a-half centuries later: it was a conception of a universal law of nations, of individuals socially

${ }^{74}$ E Jiménez de Aréchaga, El Derecho Internacional Contemporáneo (Tecnos, 1980), at 207-208; and cf. A Cassese, International Law (OUP, 2001), at 79-85.

75 The subjects of law are, thus, heterogeneous, he added, and theoreticians who beheld only States as such to be subjects simply distorted reality, failing to take into account the transformations undergone by the international community, which came to admit that non-state actors also possess international legal personality; J Barberis, 'Nouvelles questions concernant la personnalité juridique internationale', (1983) 179 RCADI 145, at 161, 169, 171-172, $178,181$.

${ }^{76}$ Cf., e.g., A A Cançado Trindade, The Application of the Rule of Exhaustion of Local Remedies in International Law, supra n. 2; A Z Drzemczewski, European Human Rights Convention in Domestic Law, (Clarendon Press, 1983), at 20-34, 341; F Matscher, 'La Posizione Processuale dell'Individuo come Ricorrente dinanzi agli Organi della Convenzione Europea dei Diritti dell'Uomo,' in Studi in Onore di Giuseppe Sperduti (Giuffrè, 1984); J A Carrillo Salcedo, Dignidad frente a Barbarie-La Declaración Universal de Derechos Humanos, Cincuenta Años Después (Trotta, 1999); E-I A Daes (rapporteur spécial), La condition de l'individu et le Droit international contemporain, UN doc. E/CN.4/Sub.2/1988/33, of 18 July 1988; R A Mullerson, 'Human Rights and the Individual as Subject of International Law: A Soviet View', (1990) 1 European Journal of International Law 33.

77 A A Cançado Trindade, 'Co-existence and Co-ordination of Mechanisms of International Protection..., supra n. 6, at 32-3. 
organized in States and also composing humanity (...); redress of violations of (human) rights, in fulfilment of an international need, owed its existence to the law of nations, with the same principles of justice applying to both States and individuals or peoples forming them.

(...) There is a growing and generalized acknowledgement that human rights, rather than deriving from the State (or from the will of individuals composing the State), all inhere in the human person, in whom they find their ultimate point of convergence. (...) The non-observance of human rights entails the international responsibility of States for treatment of the human person 78

The international subjectivity of the human being (whether a child, an elderly person, a person with disability, a stateless person, or any other) erupted indeed with all vigour in the legal science of the twentieth century, as a reaction of the universal juridical conscience against the successive atrocities committed against the human kind. An eloquent testimony of the erosion of the purely inter-state dimension of the international legal order is found in the historical and pioneering Advisory Opinion n. 16 of the Inter-American Court, on the Right to Information on Consular Assistance in the Framework of the Guarantees of the Due Process of Law (of 1 October 1999) ${ }^{79}$ which has served as orientation to other international tribunals and has inspired the evolution in statu nascendi of the international case-law on the matter ${ }^{80}$ The IACtHR recognized, in the light of the impact of the corpus iuris of the international law of human rights on the international legal order itself, the crystallization of a true individual subjective right to information on consular assistance ${ }^{81}$ of which is titulaire every human being deprived of his freedom in another country, ${ }^{82}$ furthermore, it broke away

${ }_{78}$ Ibid., 411-412.

79 IACtHR, Advisory Opinion OC-16/99, Series A, n. 16, at 3-123, paras. 1-141, and resolutory points 1-8.

80 I have more recently revisited this point, within the ICJ, in my lengthy Separate Opinion (paras. 81, 158-188) in the case A S Diallo (Guinea v D R Congo, Merits, Judgment of 30 November 2010).

81 Set forth in article 36 of the 1963 Vienna Convention on Consular Relations and linked to the guarantees of the due process of law under Article 8 of the American Convention on Human Rights.

82 In that Opinion, the Inter-American Court lucidly pointed out that the rights set forth in article 36(1) of the Vienna Convention on Consular Relations of 1963 have the characteristic that their titulaire is the individual. In effect, this provision is unequivocal in stating that the rights to consular information and notification are accorded' to the interested person. In 
from the traditional purely inter-state outlook of the matter ${ }^{83}$ bringing support to numerous individuals victimized by poverty, discrimination, and deprived of freedom abroad.

The subsequent Advisory Opinion n. 17 of the Inter-American Court, on the Juridical Condition and Human Rights of the Child (of 28 August 2002), fits into the same line of assertion of the juridical emancipation of the human being, in stressing the consolidation of the juridical personality of the child, as a true subject of law and not simple object of protection, and irrespective of the extent of his legal capacity to exercise his rights for himself (capacity of exercise). In this respect, the 1989 UN Convention on the Rights of the Child recognizes subjective rights to the child as a subject of law, and further reckons that, given his vulnerability or existential condition, the child needs special protection and legal representation, while remaining a titulaire of rights; this is in accordance with the Kantian conception of every human person being ultimately an end in herself ${ }^{84}$ The juridical category of the international legal personality has not shown itself insensible to the necessities of the international community, among which appears with prominence that of providing protection to the human beings who compose it, in particular those who find themselves in a situation of special vulnerability.

this respect, article 36 is a notable exception to the essentially Statist nature of the rights and obligations set forth elsewhere in the Vienna Convention on Consular Relations; as interpreted by this Court in the present Advisory Opinion, it represents a notable advance in respect of the traditional conceptions of International Law on the matter (para. 82, emphasis added).

83 This Opinion, pioneering in international case-law, has had a remarkable impact in the countries of the region, which have sought to harmonize their practice with it, aiming at putting an end to abuses on the part of the police and to discrimination against poor and illiterate foreigners (mainly migrants), often victimized by all sorts of discrimination (also de iure) and injustice. The Inter-American Court thus gave a considerable contribution to the evolution itself of the law in this respect.

84 D Youf, Penser les droits de l'enfant (PUF, 2002), at 93-6, 100, 118-9; and cf. F DekeuwerDéfossez, Les droits de l'enfant (PUF, 2001), at 4-5, 22, 74. 


\section{The Attribution of Duties to the Individual Directly by International Law}

To the legal doctrine of the second half of the twentieth century it did not pass unnoticed that individuals, besides being titulaires of rights at the international level, also have duties which are attributed to them by international law itself. And, what is more significant, the grave violation of those duties, reflected in the crimes against humanity, engages the international individual penal responsibility, independently from what provides the domestic law on the matter ${ }^{85}$ Contemporary developments in international criminal law have, in fact, a direct incidence in the crystallization of both of the international individual penal responsibility (the individual subject, both active and passive, of international law, titulaire of rights as well as bearer of duties emanated directly from the law of nations (droit des gens)), as well as the principle of universal jurisdiction.

The work of contemporary international criminal tribunals has given a new impetus to the struggle of the international community against impunity, as a violation per se of human rights ${ }^{86}$ besides reasserting the international criminal responsibility of the individua ${ }^{87}$ for such violations, thus seeking to prevent future crimes ${ }^{88}$ The process of criminalization of the grave violations of human rights and of international humanitarian law ${ }^{89}$ has, in effect, accompanied pari

85 M C Bassiouni, Crimes against Humanity in International Criminal Law (Kluwer, 1999), at 106, 118.

${ }^{86}$ W A Schabas, 'Sentencing by International Tribunals: A Human Rights Approach', (1997) 7 Duke Journal of Comparative and International Law 461.

87 Cf., in this respect, e.g., D Thiam, 'Responsabilité internationale de l'individu en matière criminelle,' in International Law on the Eve of the Twenty-First Century-Views from the International Law Commission / Le droit international à l'aube du XXe siècle-Réflexions de codificateurs (UN, 1997).

${ }^{88}$ For a pioneering study, cf. C T Eustathiades, 'Les sujets du droit international et la responsabilité internationale-Nouvelles tendances' (1953) 84 RCADI 401. For historical antecedents of a (permanent) international criminal jurisdiction, cf., inter alia, M R Marrus, The Nuremberg War Crimes Trial 1945-1946-A Documentary History (Bedford Books, 1997); M C Bassiouni, 'From Versailles to Rwanda in Seventy-Five Years: The Need to Establish a Permanent International Criminal Court', (1997) 10 Harvard Human Rights Journal 11.

${ }^{89}$ Cf. G Abi-Saab, 'The Concept of International Crimes' and Its Place in Contemporary International Law, in J H H Weiler et al (eds), International Crimes of State-A Critical Analysis of the ILC's Draft Article 19 on State Responsibility (W de Gruyter, 1989), at 141-50; B Graefrath, 'International Crimes-A Specific Regime of International Responsibility of States and Its Legal Consequences,' in ibid., at 161-9; P-M Dupuy, 'Implications of the Institutionalization of International Crimes of States,' in ibid., at 170-85; M Gounelle, 'Quelques remarques sur la 
passu the evolution of contemporary international law itself: the establishment of a (permanent) international criminal jurisdiction is regarded in our days as an element which enhances international law itself, bridging a basic gap and overcoming its insufficiencies of the past. Attention is to be drawn to the superior universal values, underlying the whole theme of the creation of a permanent international criminal jurisdiction. The crystallization of the international criminal responsibility of individuals (parallel to the responsibility of the state), and the process of criminalization of grave violations of human rights and of international humanitarian law, constitute elements of crucial importance to the struggle against impunity, ${ }^{90}$ and to the treatment to be dispensed to past violations, in the protection of human rights.

The consolidation of the international legal personality of individuals, as active as well as passive subjects of international law, enhances accountability in international law for abuses perpetrated against human beings. Thus, individuals are also bearers of duties under international law, and this reflects the consolidation of their international legal personality ${ }^{91}$ Developments in international legal personality and international accountability go hand in hand, and this whole evolution bears witness of the formation of the opinio iuris communis to the effect that the gravity of certain violation of fundamental rights of the human person affects directly basic values of the international community as a whole 92

In an intervention in the debates of 12 March 1986 of the Vienna Conference on the Law of Treaties between States and International Organizations or between International Organizations, I deemed it fit to warn as to the manifest incompatibility with ius cogens of the voluntarist conception of international law ${ }^{93}$ To the objective international responsibility of the states corresponds nec-

notion de crime international' et sur l'évolution de la responsabilité internationale de l'État,' in Mélanges offerts à P. Reuter-Le droit international: unité et diversité (Pédone, 1981), at 315-26.

${ }^{90}$ In the case of Paniagua Morales and Others $v$ Guatemala (also known as the case of the White Van), the IACtHR, in clearly warning as to the states' duty to combat impunity, had the occasion, in its judgment on the merits (8 March 1998) on the case, to set forth its own conceptualization of impunity (cf. para. 174).

91 H-H Jescheck, 'The General Principles of International Criminal Law Set Out in Nuremberg, as Mirrored in the ICC Statute', (2004) 2 Journal of International Criminal Justice 43.

92 Cf., e.g., A Cassese, 'Y a-t-il un conflit insurmontable entre souveraineté des États et justice pénale internationale?,' in A Cassese and M Delmas-Marty (eds), Crimes internationaux et juridictions internationales (PUF, 2002), at 15-29; and cf., generally J A Carrillo Slacedo (ed), La Criminalización de la Barbarie: La Corte Penal Internacional (Consejo General del Poder Judicial, 2000).

93 Cf. United Nations Conference on the Law of Treaties between States and International 
essarily the notion of objective illegality (one of the elements underlying the concept of ius cogens). In our days, no one would dare to deny the objective illegality of systematic practices of torture, of summary and extra-legal executions, and of enforced disappearance of persons, practices which constitute crimes against humanity, condemned by the universal juridical conscience ${ }^{94}$ parallel to the application of treaties.

Furthermore, no one would dare to deny that such grave violations of human rights and international humanitarian law, as well as the persistent denial of the most basic guarantees of the due process of law, constitute an affront to the universal juridical conscience, and clash in effect with the peremptory norms of ius cogens. This whole doctrinal evolution points in the direction of the consolidation of obligations erga omnes of protection, i.e., obligations pertaining to the protection of human beings owed to the international community as a whole. This development is essential to advances in the struggle against the arbitrary power and in the strengthening of the protection of the human person against contemporary acts of barbarism and current atrocities 95

Organizations or between International Organizations (Vienna, 1986)-Official Records (UN, 1995), vol. I, at 187-8 (intervention of A A Cançado Trindade, Deputy Head of the Delegation of Brazil). In effect, the aforementioned voluntarist conception appears incapable of explaining the very formation of rules of general international law and the incidence on the process of formation and evolution of contemporary international law of elements independent from the free will of states.

94 In a study published in a book commemorative of the fiftieth anniversary of the UN High Commissioner for Refugees (UNHCR), I sought to conceptualize what I deem it fit to name the universal juridical conscience; cf. A A Cançado Trindade, 'Reflexiones sobre el Desarraigo como Problema de Derechos Humanos frente a la Conciencia Jurídica Universal,' in A A Cançado Trindade and J Ruiz de Santiago (eds), La Nueva Dimensión de las Necesidades de Protección del Ser Humano en el Inicio del Siglo XXI (UNHCR, 2001), at 19.

95 Cf., recently, A A Cançado Trindade, 'Jus Cogens: The Determination and the Gradual Expansion of Its Material Content in Contemporary International Case-Law', XXXV Curso de Derecho Internacional Organizado por el Comité Jurídico Interamericano-2008 (OAS General Secretariat, 2009), at 3. 


\section{Subjective Right, Human Rights and the New Dimension of the International Juridical Titularity of the Human Person}

The international juridical titularity of the human person, as the so-called "founding fathers" of international law (the law of nations, the droit des gens) foresaw it, is nowadays a reality. Furthermore, the (active) international subjectivity of the individuals responds to a true necessity of their legitimatio ad causam (cf. supra), to vindicate their rights, emanated directly from international law. In the ambit of the international law of human rights, in the regional (European, inter-American and African) systems of protection-endowed with international tribunals in operation-one recognizes today, parallel to the legal personality, also the international procedural capacity (locus standi in judicio) of the individuals.

This is a logical development, as it would not appear reasonable to conceive rights at the international level without the corresponding procedural capacity to vindicate them; the individual applicants are effectively the true complaining party in the international contentieux of human rights. Upon the right of individual petition is erected the juridical mechanism of the emancipation of the human person vis-à-vis the state itself for the protection of her rights in the ambit of the international law of human rights, ${ }^{96}$ an emancipation which constitutes, in our days, a true juridical revolution, which comes at last to give an ethical content to the norms of both public domestic law and international law.

On the basis of this remarkable development lies the principle of respect for the dignity of the human person, irrespective of her existential condition. By virtue of this principle, every human being, independently of his situation and of the circumstances in which he finds himself, has the right to dignity ${ }^{97}$ The whole remarkable development of the jusinternationalist doctrine in this respect,

96 If the aforementioned right of petition had not been originally conceived and consistently understood in this way, very little would the international protection of human rights have advanced in more than six decades of evolution. With the consolidation of the right of individual petition before the international tribunals of human rights, the international protection has attained its majority.

97 On this principle, cf., e.g., B Maurer, Le principe de respect de la dignité humaine et la Convention Européenne des Droits de l'Homme (CERIC, 1999); Le principe du respect de la dignité de la personne humaine (Actes du Séminaire de Montpellier de 1998) (Council of Europe, 1999), at 15; E Wiesel, 'Contre l'indifférence,' in F Mayor (ed), Agir pour les droits de l'homme au XXIe. siècle (UNESCO, 1998), at 87-90. 
along the twentieth century, finds its roots, and it could not be otherwise, in some reflections of the past, in the juridical as well as philosophical thinking, ${ }^{98}$ as exemplified, inter alia (to refer to one which goes far back in time), by the Kantian conception of the human person as an end in itself. This is ineluctable, as it reflects the process of maturing and refinement of the human spirit itself, which renders possible the advances in the human condition itself.

In effect, one cannot dissociate the recognition of the international legal personality of the individual (supra) from the dignity itself of the human person. In a wider dimension, the human person is the being which brings within herself her supreme, and who abides by it throughout the journey of her life, under her own responsibility. In effect, it is the human person, essentially endowed with dignity, who articulates, expresses and introduces the "Sollen" of the values in the world of the reality wherein she lives, and it is only her who is capable of doing so, as bearer of such ethical values. The legal personality, for its part, is manifested as a juridical category in the universe of Law, as the unitary expression of the aptitude of the human person to be titulaire of rights and bearer of duties at the level of regulated behaviour and human relations 99

It may be recalled, in the present context, that the conception of individual subjective right has already a wide historical projection, originated in particular in the jusnaturalist thinking in the seventeenth and eighteenth centuries, and systematized in the legal doctrine throughout the nineteenth century. However, in the nineteenth century and the beginning of the twentieth century, that conception remained situated in the ambit of domestic public law, emanated from the public power, and under the influence of legal positivism 100

The subjective right was conceived as a prerrogative of the individual as defined by the legal order at issue (the objective law) ${ }^{101}$ Despite that, one cannot deny that the crystallization of the concept of individual subjective right, and its systematization, achieved at least an advance towards a better comprehension of the individual as titulaire of rights. And they rendered it possible to attain, with the emergence of human rights at the international level, the gradual overcoming of positive law. By the mid-twentieth century, the impossibility became clear of the evolution of law itself without the individual subjective

\footnotetext{
98 For an examination of the individual subjectivity in philosophical thinking, cf., e.g., A Renaut, L'ère de l'individu-Contribution à une histoire de la subjectivité (Gallimard, 1991).

99 Cf., in this sense, e.g., L Recaséns Siches, Introducción al Estudio del Derecho (Porrúa, 1997), at 150-1, 153, 156, 159.

${ }^{100}$ L Ferrajoli, Derecho y Razón-Teoría del Garantismo Penal (Trotta, 2001), at 912-3.

${ }^{101}$ C Eisenmann, 'Une nouvelle conception du droit subjectif: la théorie de M. Jean Dabin', (1954) 60 Revue du droit public et de la science politique en France et à l'étranger 753, esp. at 754-5, 771.
} 
right, expression of a true human right 102

As I deemed it fit to sustain in my Concurring Opinion in the historical Advisory Opinion n. 16 of the IACtHR on the Right to Information on Consular Assistance in the Ambit of the Guarantees of the Due Process of Law (of 1 October 1999), we nowadays witness

the process of humanization of international law, which today encompasses also this aspect of consular relations. In the confluence of these latter with human rights, the individual subjective right to information on consular assistance, of which are titulaires all human beings who are in the need to exercise it, has crystallized: such individual right, situated into the conceptual universe of human rights, is nowadays supported by conventional international law as well as by customary international law 103

The emergence of universal human rights, as from the proclamation of the Universal Declaration of 1948, came to widen considerably the horizon of contemporary legal doctrine, disclosing the insufficiencies of the traditional conceptualization of the subjective right. The pressing needs of protection of the human being much fostered this development. Universal human rights, superior and anterior to the state and to any form of socio-political organization, and inherent to the human being, asserted themselves as opposable to public power itself. Human rights freed the conception of subjective right (supra) from the chains of legal positivism. If, on the one hand, the juridical category of the international legal personality of the human being contributed to instrumentalize the vindication of the rights of the human person, emanated from international law-on the other hand the corpus iuris of universal human rights ascribed to the legal personality of the individual a far wider dimension, no longer conditioned to the law emanated from the public state power.

102 J Dabin, El Derecho Subjetivo (Rev. de Derecho Privado, 1955), at 64.

${ }^{103}$ Para. 35. On the impact of this Advisory Opinion n. 16 (1999) of the IACtHR on contemporary international case-law and practice, cf. A A Cançado Trindade, 'The Humanization of Consular Law: The Impact of Advisory Opinion n. 16 (1999) of the Inter-American Court of Human Rights on International Case-Law and Practice', (2007) 6 Chinese Journal of International Law 1 , at $\mathrm{n} .1$. 


\section{The Erosion of the Inter-State Outlook of Adjudication by the ICJ}

I have recently had the occasion, in my Separate Opinion appended to the Advisory Opinion of the ICJ on the Revision of a Judgment of the ILO Administrative Tribunal upon a Complaint Filed against IFAD (1 February 2012), to dwell upon the outdated dogmatism of the PCIJ and ICJ Statutes, in so far as the international legal capacity of individuals is concerned. As I have recalled in that Separate Opinion (paras. 70-75), the question of the procedural capacity of the individuals before the ICJ, and its predecessor the Permanent Court of International Justice (PCIJ), was effectively considered on the occasion of the original drafting, by the Advisory Committee of Jurists appointed by the old League of Nations, of the Statute of the PCIJ, in 1920 104

Of the ten members of the aforementioned Committee of Jurists, only two-Loder and De La Pradelle-pronounced themselves in favour of enabling the individuals to appear as parties before The Hague Court (ius standi) in contentious cases against (foreign) States. The majority of the Committee, however, was firmly opposed to this proposition: four members ${ }^{105}$ objected that the individuals were not subjects of international law (and could not, thus, in their view, be parties before the Court) and that only the states were juridical persons in the international order, in what they were followed by the other members 106

The position which prevailed in 1920-which has been surprisingly and regrettably maintained in article 34(1) of the Statute of the ICJ (formerly the PCIJ) to date, was promptly and strongly criticized in the more lucid doctrine of the epoch (already in the twenties). Thus, in his thoughtful monograph Les nouvelles tendances du Droit international (1927), Nicolas Politis pondered that the States are no more than fictions, composed as they are of individuals, and that all law ultimately aims at the human being, and nothing more than the human being: this is something "so evident", he added, that "il serait inutile d'y insister si les brumes de la souveraineté n'avaient pas obscurci les vérités

\footnotetext{
${ }^{104}$ A A Cançado Trindade, El Acceso Directo del Individuo a los Tribunales Internacionales de Derechos Humans, supra n. 47 , at 31 , and cf. at 32-5.

105 Ricci-Busatti, Baron Descamps, R Fernandes and Lord Phillimore.

${ }^{106}$ Cf. J Spiropoulos, Lindividu en Droit international (LGDJ, 1928), at 50-51; N Politis, Les nouvelles tendances du Droit international (Libr. Hachette, 1927), at 84-7; M St Korowicz, 'The Problem of the International Personality of Individuals', (1956) 50 American Journal of International Law 543.
} 
les plus élémentaires" 107 And Politis proceeded in the defence of the granting to individuals of the direct appeal to international instances to vindicate their "legitimate interests", as that would to "a true necessity of international life"

Another criticism to the solution adopted in the matter by the Statute of the PCIJ (article 34(1)) was formulated by Spiropoulos, also in the twenties. Already in 1928, he had anticipated that the emancipation of the individual from the state was a "question of time" and that the individual should be able to defend himself and his rights at the international level ${ }^{109}$ There was, he added, no impediment for conventional international law to secure to individuals a direct action at the international level (there having even been precedents in this sense in the inter-war period); if this did not occur and one would limit oneself to judicial actions at the domestic law level, not seldom the state would become "judge and party" at the same time, what would be an incongruity.

To Spiropoulos, the international legal order can be addressed itself directly to individuals (as exemplified by the peace treaties of the inter-war period), thereby erecting them into the condition of subjects of international law, to the extent that a direct relationship is established between the individual and the international legal order, which renders him "directly titulaire of rights or of obligations"; thus, one cannot fail to admit the international legal personality of the individual ${ }^{110}$ Without the granting to individuals of direct means of action at the international level, his rights will continue "without sufficient protection"; only with such direct action before an international instance, he added, an effective protection of human rights will be achieved, in conformity with the "spirit" of the new international order.

The option made by the draftsmen of the Statute of the old PCIJ, stratified with the passing of time in the Statute of the ICJ up to the present time, is even more open to criticism if we consider that, already in the first half of the twentieth century, there were experiments of international law which in effect granted international procedural status to individuals. This is exemplified by the system of the navigation of the river Rhine, by the Project of an International Prize Court (1907), by the Central American Court of Justice (1907-1917), as well as, in the era of the League of Nations, by the systems of minorities (including Upper Silesia) and of the territories under mandate, by the systems of petitions of the Islands Aaland and of the Saar and of Danzig, besides the practice of

\footnotetext{
${ }^{107}$ N Politis, ibid., 76-8, 69.

${ }^{108}$ Ibid., at 82-3, 89-90, and cf. at 92, 61.

${ }^{109} \mathrm{~J}$ Spiropoulos, supra n. 106 , at 44 , and cf. at $49,64-5$.

110 Ibid., at 50-1, 25, 31-3, 40-1.
} 
mixed arbitral tribunals and of mixed claims commissions, of the same epoch ${ }^{111}$

This evolution intensified and generalized in the era of the United Nations, with the adoption of the system of individual petitions under some universal human rights treaties of our times, in addition to human rights conventions at the regional level, which established international human rights tribunals (the European and Inter-American Courts of Human Rights $\sqrt{12}^{12}$ followed, more recently, by the African Court of Human and Peoples Rights). Thereunder the international procedural capacity of individuals came to be exercised, with their direct access to international justice ${ }^{113}$ The significance of the right of individual petition, a definitive conquest of the international law of human rights ${ }^{114}$ can only be properly assessed in historical perspective.

In my aforementioned Separate Opinion in the recent ICJ Advisory Opinion on the Revision of a Judgment of the ILO Administrative Tribunal upon a Complaint Filed against IFAD (2012), I then turned my criticisms on what I perceive as the erosion of the strict inter-State outlook of adjudication by the of adjudication by the Hague Court (paras 76-81 and 88-90). I pondered that the fact that the Advisory Committee of Jurists did not find, in 1920, that the time was ripe to grant access to the PCIJ to subjects of rights other than the states, such as the individuals, did not mean a definitive answer to the question at issue. The

111 For a study, cf., e.g.: A A Cançado Trindade, 'Exhaustion of Local Remedies in International Law Experiments Granting Procedural Status to Individuals in the First Half of the Twentieth Century,' (1977) 24 Netherlands International Law Review 373; C A Norgaard, The Position of the Individual in International Law (Munksgaard, 1962), at 109-28; M St Korowicz, Une expérience de Droit international-La protection des minorités de Haute-Silésie (Pédone, 1946), at 81-174; among others. And, for a general study, cf. A A Cançado Trindade, O Esgotamento de Recursos Internos no Direito Internacional (University of Brasília, 1997).

112 A A Cançado Trindade, El Acceso Directo del Individuo a los Tribunales Internacionales de Derechos Humans, supra n. 45, at 34-5.

${ }^{113}$ At the beginning of the exercise of the right to individual petition, such right, even if motivated by the search for individual reparation, also contributed to secure the respect for the objective obligations that were binding upon states parties. Cf., under the original text of article 25 of the European Convention of Human Rights, e.g., H Rolin, 'Le rôle du requérant dans la procédure prévue par la Commission européenne des droits de l'homme', (1956) 9 Revue hellénique de droit international 9; C T Eustathiades, "Les recours individuels à la Commission européenne des droits de l'homme," in Grundprobleme des internationalen Rechts-Festsschrift für J. Spiropoulos (Schimmelbusch \& Co., 1957), at 121; F Durante, Ricorsi Individuali ad Organi Internazionali (Giuffrè, 1958), at 129-30; K Vasak, La Convention européenne des droits de l'homme (LGDJ, 1964), at 96-8; F Matscher, 'La Posizione Processuale dell'Individuo come Ricorrente dinanzi agli Organi della Convenzione Europea dei Diritti dell'Uomo', in Studi in Onore di G. Sperduti (Giuffrè, 1984), at 601.

${ }^{114}$ A A Cançado Trindade, El Derecho Internacional de los Derechos Humanos en el Siglo XXI (Editorial Jurídica de Chile, 2001), at 317-70. 
fact that the same position was maintained at the time of adoption in 1945 of the Statute of the ICJ did not mean a definitive answer to the question at issue.

The question of access of individuals to international justice, with procedural equality, continued to occupy the attention of legal doctrine ever since, throughout the decades. Individuals and groups of individuals began to have access to other international judicial instances (cf. supra), reserving the PCIJ and later the ICJ only for disputes between states. The dogmatic position taken originally in 1920, on the occasion of the preparation and adoption of its Statute, did not hinder the PCIJ to occupy itself promptly of cases pertaining to the treatment of minorities and inhabitants of cities or territories with a juridical statute of their own. In considerations developed in the examination of such matters, the PCIJ went well beyond the inter-state dimension, taking into account the position of individuals themselves (as in, e.g., inter alia, the Advisory Opinion on the Jurisdiction of the Courts of Danzig, 1928) ${ }^{115}$ Ever since, the artificiality of such dimension became noticeable and acknowledged, already at an early stage of the case-law of the PCIJ.

The exclusively inter-state character of the contentieux before the ICJ has not appeared satisfactory at all either. At least in some cases (from 1955 to 2004), pertaining to the condition of individuals, the presence of these latter (or of their legal representatives), in order to submit, themselves, their positions, would have enriched the proceedings and facilitated the work of the Court ${ }^{116}$

115 In that Advisory Opinion (3 March 1928, Series C, No 14-I, p. 8, followed by its Advisory Opinion on Consistency of Certain Danzig Legislative Decrees with the Constitution of the Free City, 4 December 1935, Series C, No 77, p. 291), the PCIJ held that a treaty (the 1921 Danzig-Polish Agreement) conferred rights directly upon the individuals concerned (railway employees). They could thus lodge personal pecuniary claims (e.g., salaries, and pensions), even though they had passed from the service of the Free City of Danzig into the jurisdiction of Poland. Thus, as early as in 1928, the PCIJ had the courage and vision to determine, in its Advisory Opinion on the Jurisdiction of the Courts of Danzig, that, in the circumstances of the matter brought into its cognizance, individuals can be subjects of rights and bearers of obligations emanating directly from international law, from an international treaty. That finding by the PCIJ was to have repercussions in the following United Nations era. Thus, the new Court, the ICJ, in its Advisory Opinion of 1950 on the International Status of South West Africa, ICJ Reports 1950, p. 128, held that the inhabitants of the mandated territories had (even irrespective of a bilateral treaty) a right to petition the [former] UN Trusteeship Council, under article 80 of the UN Charter. From all the aforesaid, it is clear that, by the mid-twentieth century, the individuals international legal standing, and the need to secure a procès équitable (also in the emerging law of international organizations) were already recognized.

116 One may recall, for example, the classical Nottebohm case concerning double nationality (Nottebohm Case (second phase), ICJ Reports 1955, p. 4); the case concerning the Application 
In those cases, one cannot fail to reckon that one of their predominant elements was precisely the concrete situation of the individuals directly affected, and not merely abstract issues of exclusive interest of the litigating States in their relations inter se. Moreover, one may further recall that, in the case of Armed Activities in the Territory of Congo (D R. Congo v Uganda, 2000) the ICJ was concerned with grave violations of human rights and of international humanitarian law; in the Land and Maritime Boundary between Cameroon and Nigeria (1996), it was likewise concerned with the victims of armed clashes.

More recent examples wherein the Court's concerns have gone beyond the inter-State outlook include, e.g., the case on Questions Relating to the Obligation to Prosecute or Extradite (Belgium v Senegal, 2009) pertaining to the principle of universal jurisdiction under the UN Convention against Torture, the case of A S Diallo (Guinea $v D R$ Congo, 2010) on detention and expulsion of a foreigner, the case of the Jurisdictional Immunities of the State (Germany $v$ Italy, counter-claim, 2010; and merits, 2012), the case of the Application of the International Convention on the Elimination of All Forms of Racial Discrimination (Georgia $v$ Russian Federation, 2011), the case of the Temple of Preah Vihear (Cambodia $v$ Thailand, provisional measures of protection, 2011).

Further examples can be found in the ICJ two most recent Advisory Opinions, namely, the Advisory Opinion on the Declaration of Independence of Kosovo (2010), and the Advisory Opinion of the ICJ on the Revision of a Judgment of the ILO Administrative Tribunal upon a Complaint Filed against IFAD (2012). In all these recent cases and Advisory Opinions, one cannot fail to recognize that a key element-at times the predominant one-has precisely been the concrete situation of human beings, and not mere abstract questions of exclusive interest of the contending states in their relations inter se. [This is what the droit détatistes, fascinated with that they regard as the "art" of litigation, and eager "to win a case" before the World Court, fail to see].

The truth remains that the artificiality of the exclusively inter-state outlook of the procedures before the ICJ is clearly disclosed the very nature of some of

of the Convention of 1902 Governing the Guardianship of Infants (Netherlands v Sweden), ICJ Reports 1958, p. 55; the cases of the Trial of Pakistani Prisoners of War (Pakistan v India) (1973), of the United States Diplomatic and Consular Staff in Teheran case, ICJ Reports 1980, p. 3, of the East-Timor (Portugal v Australia), ICJ Reports 1995, p. 90; the case of the Application of the Convention against Genocide (Bosnia-Herzegovina v Yugoslavia), ICJ Reports 2007, p. 43; and the three successive cases concerning consular assistance-namely, Vienna Convention on Consular Relations (Paraguay v United States of America) (1998), LaGrand (Germany v United States), ICJ Reports 2001, p. 466, and Avena and Others (Mexico v United States), ICJ Reports 2004, p. 12. 
the cases submitted to it. Such artificiality has been criticised, time and time again, in expert writing, including by a former President of the Court itself. It was recalled that "nowadays a very considerable part of international law" (e.g., lawmaking treaties) "directly affects individuals", and the effect of srticle 34(1) of the ICJ Statute has been "to insulate" the Court "from this great body of modern international law". The ICJ remains

trapped by Article 34(1) in the notions about international law structure of the 1920s. (...) [I]t is a matter for concern and for further thought, whether it is healthy for the World Court still to be, like the international law of the 1920s, on an entirely different plane from that of municipal courts and other tribunals ${ }^{117}$

To the same effect, Rosenne expressed the view, already in 1967, that there was "nothing inherent in the character of the International Court itself to justify the complete exclusion of the individual from appearing before the Court in judicial proceedings relating of direct concern to him" 118 The current practice of exclusion of the locus standi in iudicio of the individuals concerned from the proceedings before the ICJ, he added, in addition to being artificial, could also produce "incongruous results". It was thus highly desirable that that scheme be reconsidered, in order to grant locus standi to individuals in proceedings before the ICJ, as

it is in the interests of the proper administration of international justice that in appropriate cases the International Court of Justice should take advantage of all the powers which it already possesses, and permit an individual directly concerned to present himself before the Court, (...) and give his own version of the facts and his own construction of the law 119

$\overline{117}$ R Y Jennings, 'The International Court of Justice after Fifty Years', (1995) 89 American Journal of International Law 504.

${ }^{118}$ S Rosenne, 'Reflections on the Position of the Individual in Inter-State Litigation in the International Court of Justice,' in P Sanders (ed), International Arbitration-Liber Amicorum for M. Domke (Nijhoff, 1967), at 249, and cf. 242.

119 Ibid., at 250, and cf. at 243. 


\section{The international juridical capacity of the individual}

Parallel to the construction of their international juridical personality, the access of individuals to contemporary international tribunals for the protection of their rights reveals a renovation of international law, in the sense of its aforementioned humanization $\sqrt{120}$ opening a great gap in the traditional doctrine of the reserved domain of states ${ }^{121}$ (or compétence nationale exclusive), definitively overcome: the individual is erected as subject of international law ${ }^{122}$ endowed with procedural capacity. Before internationals tribunals, the human person encounters herself, to protect herself from the arbitrariness of the State, being protected by the rules of international law ${ }^{123}$

This renovation of international law, proper of our time, corresponds to the recognition of the necessity that all states, in order to avoid new violations of human rights, are to respond for the way they treat all human beings who are under their jurisdiction. Such renovation would simply not have been possible without the crystallization of the right of individual petition, amidst the recognition of the objective character of the obligations of protection and the acceptance of the collective guarantee of compliance with them: this is the real sense of the historical rescue of the individual as subject of the international law of human rights (cf. supra).

The counterposition between the complainant individual and the respondent state in cases of alleged violations of protected rights is the essence of the international protection of human rights. The profound transformation of the international legal order, launched by the emergence of the international law of human rights, has not taken place without difficulties, precisely for requiring a new mentality. It has furthermore undergone stages, some of which no longer sufficiently studied in our days, even in respect of the crystallization of the right

${ }^{120}$ Cf. A A Cançado Trindade, 'El Nuevo Reglamento de la Corte Interamericana de Derechos Humanos (2000): La Emancipación del Ser Humano como Sujeto del Derecho Internacional de los Derechos Humanos', (2001) 30/31 Revista del Instituto Interamericano de Derechos Humanos 45; A A Cançado Trindade, 'Hacia la Consolidación de la Capacidad Jurídica Internacional de los Peticionarios en el Sistema Interamericano de Protección de los Derechos Humanos', (2003) 37 Revista del Instituto Interamericano de Derechos Humanos 13.

${ }^{121}$ F A von der Heydte, op. cit. infra n. 129, at 332-3 and 329-30; and cf. A A Cançado Trindade, 'The Domestic Jurisdiction of States in the Practice of the United Nations and Regional Organisations', (1976) 25 International and Comparative Law Quarterly 715.

${ }^{122}$ F.A. von der Heydte, infra n. 130, at 345.

${ }^{123}$ Ibid., at 356-7, 301-2. 
of individual petition.

Already in the beginnings of the exercise of this right it was stressed that, though motivated by the search for individual reparation, the right of petition contributes also to secure the respect for obligations of an objective character which bind the States Parties ${ }^{124}$ In various cases the exercise of the right of petition has gone further, occasioning changes in the domestic legal order and in the practice of the public organs of the state. The significance of the right of individual petition can only be properly assessed in historical perspective.

Consideration of the right of individual petition as a method of international implementation of human rights has necessarily to take into account the central aspect of the legitimatio ad causam of petitioners and the conditions of the exercise and of the admissibility of petitions (set forth in the distinct human rights instruments which foresee them) 125 Under the European Convention of Human Rights, a vast case-law on the right of individual petition has developed, recognizing its autonomy, in respect of the substantive rights listed in titled I of the European Convention. In the inter-American system of human rights protection, the right of individual petition has constituted itself in an effective way to face not only individual cases but also cases of massive and systematic violations of human rights. Its importance has been fundamental, and could never be minimized.

The American Convention goes beyond the European Convention: the legitimatio ad causam, which extends itself to every and any petitioner, can prescind even from some manifestation on the part of the victim herself. The right of individual petition, thus widely conceived, has as immediate effect that of widening the scope of protection, mainly in cases wherein the victims (e.g., incommunicado detainees, enforced disappeared persons, among other situations) find themselves unable to act on their own, and stand in need of the

${ }^{124}$ For example, under the original article 25 of the European Convention on Human Rights; cf. H Rolin, 'Le rôle du requérant dans la procédure prévue par la Commission européenne des droits de l'homme' (1956), 9 Revue hellénique de droit international 3, esp. at 9; C T Eustathiades, 'Les recours individuels à la Commission européenne des droits de l'homme', in Grundprobleme des internationalen Rechts-Festschrift für J. Spiropoulos (Schimmelbusch \& Co., 1957), at 121; F Durante, Ricorsi Individuali ad Organi Internazionali (Giuffrè, 1958), at 125-52, esp. at 129-30; K Vasak, La Convention européenne des droits de l'homme (LGDJ, 1964), at 96-8; $M$ Virally, 'Laccès des particuliers à une instance internationale: la protection des droits de l'homme dans le cadre européen', (1964) 20 Mémoires Publiés par la Faculté de Droit de Genève 67; H Mosler, 'The Protection of Human Rights by International Legal Procedure', (1964) 52 Georgetown Law Journal 800.

${ }^{125}$ For an examination of the matter, cf. A A Cançado Trindade, Tratado de Direito Internacional dos Direitos Humanos, supra n. 49, at 68-87. 
initiative of a third "party" as petitioner on their behalf and defence $\sqrt{126}$ With the access of individuals to justice at the international level, by means of the exercise of the right of individual petition, a concrete expression has been given to the recognition that the human rights to be protected are inherent to the human person and do not derive from the state. Accordingly, the action in their protection is not exhausted-cannot be exhausted-in the action of the state.

Each of the procedures which regulate the right of individual petition under international treaties and instruments of human rights, despite their differences in their juridical nature, has contributed, in their own way, to the gradual strengthening of the procedural capacity of the complainant at the international level. ${ }^{127}$ In effect, of all the mechanisms of international protection of human rights, the right of individual petition is, effectively, the most dynamic one, in even attributing the initiative of action to the individual himself (the ostensibly weaker party vis-à-vis the public power), distinctly from the exercise ex officio of other methods (such as those of reports and investigations) on the part of the organs of international supervision. It is the one which best reflects the specificity of the international law of human rights, in comparison with other solutions proper of public international law.

The ineluctable and indispensable complement of the right of international individual petition lies in the intangibility and preservation of the integrity

${ }^{126}$ The denationalization of protection and the requisites of the international action of safeguard of human rights, besides widening sensibly the circle of protected persons, enabled the individual to exercise rights emanated directly from international law (droit des gens), implemented in the light of the aforementioned notion of collective guarantee, and no longer simply conceded by the state.

${ }^{127}$ In express recognition of the relevance of the right of individual petition, the Declaration and Programme of Action of Vienna, main (final) document adopted by the II World Conference of Human Rights (1993), urged its adoption, as an additional method of protection, by means of Optional Protocols to the Convention on the Elimination of All Forms of Discrimination against Women (already adopted) and to the Covenant on Economic, Social and Cultural Rights (recently adopted); cf. Declaration and Programme of Action of Vienna of 1993, part II, paras 40 and 75 , respectively. That document recomended, moreover, to states parties to human righs treaties, the acceptance of all available optional procedures of individual petitions or communications (cf. ibid., part II, para. 90). For an assessment of the results of the II World Conference of Human Rights (Vienna, 1993), cf. A A Cançado Trindade, 'Memória da Conferência Mundial de Direitos Humanos (Viena, 1993)', (1993-1994) 87/90 Boletim da Sociedade Brasileira de Direito Internacional 9; A A Cançado Trindade, 'Balance de los Resultados de la Conferencia Mundial de Derechos Humanos (Viena, 1993),' in Estudios Básicos de Derechos Humanos (IIDH, 1995), vol. III, at 17; A A Cançado Trindade, 'A Conferência Mundial de Direitos Humanos: Lições de Viena', (1994) 10 Revista da Faculdade de Direito da Universidade Federal do Rio Grande do Sul 232. 
of the jurisdiction of international tribunals of human rights ${ }^{128}$ In this respect, both the IACtHR, in its historical judgments in the cases of the Tribunal Constitucional and of Ivcher Bronstein versus Peru (jurisdiction, 1999), and of Hilaire, Constantine and Benjamin and Others versus Trinidad and Tobago (preliminary objection, 2001), as well as ECtHR, in its landmark judgments in the cases of Belilos $v$ Switzerland (1988), of Loizidou $v$ Turkey (preliminary objections, 1995), and of Ilascu, Lesco, Ivantoc and T Petrov-Popa v Moldova and the Russian Federation (2001), have advanced their shared understanding that their respective jurisdictions on contentious matters could not be conditioned by acts distinct from their own; the two Courts duly discarded the voluntarist conception, and thus rightly preserved the integrity of the mechanisms of protection of the American and the European Convention of Human Rights, respectively $[129$

\section{Personality and Capacity: The Individual's Access to Justice at International Level}

Ultimately, all law exists for the human being, and the law of nations is no exception to that, guaranteeing to the individual his rights and the respect for his personality ${ }^{130}$ as well as the capacity to exercise his rights. The state-it is nowadays widely acknowledged-is responsible for all its acts-both iure gestionis and iure imperii-as well as for all its omissions, in breach of human rights. In case of violation of human rights, the direct access of the individual to the international jurisdiction has been reckoned as being fully justified, in order to enable him to vindicate such rights, even against his own state. With the emergence of the international law of human rights (cf. infra), the necessity

${ }^{128}$ For a study, cf. A A Cançado Trindade, El Acceso Directo del Individuo a los Tribunales Internacionales de Derechos Humans, supra n. 45, at 17-96, esp. at 61-76. And, on this particular point, cf. A A Cançado Trindade, El Ejercicio de la Función Judicial Internacional-Memorias de la Corte Interamericana de Derechos Humanos (Del Rey, 2011), ch. I, at 5-10.

${ }^{129}$ A A Cançado Trindade, El Desarrollo del Derecho Internacional de los Derechos Humanos mediante el Funcionamiento y la Jurisprudencia de la Corte Europea y la Corte Interamericana de Derechos Humanos (IACtHR, 2007), at 17-8, 41-2.

${ }^{130}$ F A von der Heydte, 'L'individu et les tribunaux internationaux', (1962) 107 RCADI 301; cf. also, in this respect, e.g., E M Borchard, 'The Access of Individuals to International Courts', (1930) 24 American Journal of International Law 359. 
of the legitimatio ad causam of individuals in international law has found growing support in legal doctrine ${ }^{131}$

The respect for the individual's personality at the international level is instrumentalized by the international right of individual petition. It is for this reason that, in my Concurring Opinion in the case of Castillo Petruzzi and Others v Peru (Preliminary Objections, Judgment of 4 September 1998) before the Inter-American Court of Human Rights (IACtHR), urged by the circumstances of the cas d'espèce, I saw it fit to characterize such international right of individual petition as a fundamental clause (cláusula pétrea) of the human rights treaties which provide for it ${ }^{132}$ adding that:

The right of individual petition shelters, in fact, the last hope of those who did not find justice at the national level. I would not refrain myself nor hesitate to add-allowing myself the metaphorthat the right of individual petition is undoubtedly the most luminous star in the universe of human rights ${ }^{133}$

Human rights do assert themselves against all forms or domination or arbitrary power ${ }^{134}$ In the public hearings before the IACtHR (mainly those pertaining to

${ }^{131}$ Cf. A A Cançado Trindade, El Acceso Directo del Individuo a los Tribunales Internacionales de Derechos Humans, supra n. 45, at 17-96; A A Cançado Trindade, 'The Procedural Capacity of the Individual as Subject of International Human Rights Law: Recent Developments,' in K Vasak (ed.), Amicorum Liber-Les droits de l'homme à l'aube du XXIe siècle (Bruylant, 1999), at 521; A A Cançado Trindade, 'Vers la consolidation de la capacité juridique internationale des pétitionnaires dans le système interaméricain des droits de la personne,' supra n. 47, at 207-39; A A Cançado Trindade, 'El Nuevo Reglamento de la Corte Interamericana de Derechos Humanos (2000): La Emancipación del Ser Humano como Sujeto del Derecho Internacional de los Derechos Humanos', (2001) 30/31 Revista del Instituto Interamericano de Derechos Humanos 45.

132 To which one can add, insofar as the American Convention on Human Rights is concerned, the other fundamental clause (cláusula pétrea) of the recognition of the competence of the Inter-American Court of Human Rights in contentious matters; for a study, cf. A A Cançado Trindade, 'Las Cláusulas Pétreas de la Protección Internacional del Ser Humano: El Acceso Directo de los Individuos a la Justicia a Nivel Internacional y la Intangibilidad de la Jurisdicción Obligatoria de los Tribunales Internacionales de Derechos Humanos,' in El Sistema Interamericano de Protección de los Derechos Humanos en el Umbral del Siglo XXI-Memoria del Seminario (Nov. 1999) (IACtHR, 2001), at 3.

${ }^{133}$ IACtHR, case Castillo Petruzzi and Others v Peru (Preliminary Objections), Judgment of 4 September 1998, Series C, n. 41, Concurring Opinion of Judge A A Cançado Trindade, at 62, para. 35 .

${ }^{134}$ A A Cançado Trindade, 'The Future of the International Protection of Human Rights,' in B Boutros-Ghali (ed), Amicorum Discipulorumque Liber-Paix, Développement, Démocratie 
reparations), a point which has particularly drawn my attention has been the remark, increasingly more frequent, on the part of the victims or their relatives, in the sense that, were it not for their access to the international instance, justice would never have been made in their concrete cases. Without the right of individual petition, and the consequent access to justice at the international level, the rights set forth in human rights treaties would be reduced to a little more than dead letter.

The human being emerges, at last, even in the most adverse conditions, as the ultimate subject of Law, domestic as well as international. The case of the "Street Children" (Villagrán Morales and Others v Guatemala, 1999-2001), decided by the IACtHR, the first one of the kind in which the cause of the children abandoned in the streets was brought before an international human rights tribunal ${ }^{135}$ and in which some of those marginalized and forgotten by this world succeeded to resort to an international tribunal to vindicate their rights as human beings, $\sqrt{136}$ is truly paradigmatic, and gives a clear and unequivocal testimony that the international law of human rights has nowadays achieved its maturity. As it can be inferred from this historical case of the "Street Children", the international juridical subjectivity of the individuals is nowadays an irreversible reality, and the violation of their fundamental rights, emanated directly from the international legal order, brings about juridical consequences.

As I have seen it fit to sum up in my Concurring Opinion in the aforementioned Advisory Opinion of the Inter-American Court on the Juridical Condition and Human Rights of the Child (2002),

every human person is endowed with juridical personality, which imposes limits to State power. The juridical capacity varies in virtue of the juridical condition of each one to undertake certain

(Bruylant, 1998), vol. II, at 961. On the need to overcome the current challenges and obstacles to the prevalence of human rights, cf. A A Cançado Trindade, 'L'interdépendance de tous les droits de l'homme et leur mise-en-oeuvre: obstacles et enjeux', (1998) 158 Revue internationale des sciences sociales 571.

135 IACtHR, case Villagrán Morales and Others $v$ Guatemala, Judgment (merits) of 19 November 1999, Series C, n. 63, paras 1-253, and Joint Concurring Opinion of Judges A A Cançado Trindade and A. Abreu Burelli, paras. 1-11.

${ }^{136}$ In fact, in that case of the killing of the Street Children, the mothers of the murdered children (and the grandmother of one of them), as poor and abandoned as their sons (and grandson), had access to the international jurisdiction, appeared before the Court (public hearings of 28/29 January 1999 and of 12 March 2001), and, due to the judgments of the Inter-American Court (as to the merits, of 19 November 1999, and reparations, of 26 May 2001), which brought them redress, could at least recover their faith in human justice. 
acts. Yet, although such capacity of exercise varies, all individuals are endowed with juridical personality. Human rights reinforce the universal attribute of the human person, given that to all human beings correspond likewise the juridical personality and the protection of the Law, independently of her existential or juridical condition. (par. 34)

In respect of the human rights of individuals belonging to groups or human collectivities, reference is to be made to the historical Advisory Opinion n 18, on the Juridical Condition and Rights of Undocumented Migrants (17 September 2003), of the IACtHR. The Court stressed that the migratory status cannot serve as justification for depriving them of the enjoyment and exercise of their human rights, including labour rights. The Court added that States cannot discriminate, or tolerate discriminatory situations, to the detriment of migrants, and ought to guarantee the due process of law to any person, irrespective of her migratory status.

The IACtHR further warned that States cannot subordinate or condition the observance of the fundamental principle of equality before the law and non-discrimination to the aims of their migratory or other policies. In my Concurring Opinion I sustained that this fundamental principle belonged to the domain of ius cogens, and stressed the importance of the erga omnes obligations (encompassing also inter-individual relations) vis-à-vis the rights of undocumented migrants. The Advisory Opinion of the Court thus benefitted a considerable number of persons, those belonging to numerous groups of undocumented migrants, exposed to all sorts of abuses in numerous countries nowadays.

The recognition of the direct access of individuals to international justice reveals, in these first two decades of the twenty-first century, the new primacy of the raison d'humanité over the raison d'État, to inspire the historical process of humanization of international law. Human conscience thus attains in our days a stage of evolution which renders it possible to do justice at the international level in the safeguard of those entirely marginalized or socially excluded (cf. supra). The international juridical titularity of the individuals is nowadays an irreversible reality, and the human person emerges, at last, even in the most adverse conditions, as the ultimate subject of both domestic and international law, endowed with full juridico-procedural capacity. 


\section{The Overcoming of State-Centrism: The Human Person in the Expansion of International Legal Personality}

Some learned thinkers of past decades, who were prepared to extract lessons left by the history of the twentieth century, coincide in a key point ${ }^{137}$ never as in the last century so much progress in science and technology was verified, tragically accompanied by so much destruction and cruelty. ${ }^{138}$ The twilight of the twentieth century disclosed a panorama of unprecedented scientific discovery and suffering ${ }^{139}$ In a luminous essay published more than six decades ago, in the same year of the adoption of the Universal Declaration of Human Rights, the learned historian Arnold Toynbee, questioning the very basis of what was known as civilization, that is, the very modest advances at social and moral levels, regretted that the command achieved by man over non-human nature unfortunately did not extend itself to the spiritual level.

That abuses and crimes have been committed in the name of the public state power is unjustifiable, as the state was conceived-it should not be forgottenas promoter and guarantee of the common good ${ }^{140}$ The international legal order no longer fits itself into the straight-jacket of the strict inter-State outlook, which led to some many abuses, and atrocities, in the recent past; it turns instead its attention, with the revival of jusnaturalism, to the condition of human beings, and the questions which affect the whole of humankind. ${ }^{141}$ One recognizes today the need to reinstate the human person to the central position-as $s u b$ ject of both domestic and international law-wherefrom she was unduly removed, with the disastrous consequences of sad memory.

${ }^{137}$ So well singled out, for example, in some of the last writings of Bertrand Russell, of Karl Popper, of Isaiah Berlin, among others; cf. B Russell, Knowledge and Wisdom, in H Peterson (ed), Essays in Philosophy (Pocket Library, 1960), at 498-9, 502; K Popper, The Lesson of This Century (Routledge, 1997), at 53 and 59; I Berlin, 'Return of the Volksgeist: Nationalism, Good and Bad,' in N P Gardels (ed), At Century's End (Alti Publ., 1996), at 94.

${ }^{138}$ And never, as in our times, has one registered so much increase of prosperity accompanied in an equally tragic way of so much increase-statistically proven-of socio-economic disparities and of extreme poverty.

${ }^{139}$ A J Toynbee, Civilization on Trial (Oxford University Press, 1948), at 262-4. And another historian, Eric Hobsbawn, in our days portrays the twentieth century as a period of history marked above all by the crimes and madness of man; E Hobsbawm, Era dos Extremos-O Breve Século XX (Cia. das Letras, 1996), at 561.

${ }^{140} \mathrm{~J}$ Maritain, The Person and the Common Good (University of Notre Dame Press, 1966).

${ }^{141}$ A Truyol y Serra, La Sociedad Internacional (Alianza Editorial, 1998), at 97-8, 167. 
The recognition of the centrality of human rights corresponds to a new ethos of our times. In this line of evolution also lies the current trend of "criminalization" of grave violations of the rights of the human person. At this early stage of the twenty-first century, we witness the acceleration of the historical process of humanization of international law $\left[{ }^{142}\right.$ to which it is a privilege to be able to contribute, which comes to occupy itself more directly with the realization of superior common goals.

We stand before a humanized (or even truly humanist) international ordre public, wherein the public interest or the general interest coincides fully with that of the prevalence of human rights ${ }^{143}$ That implies the recognition that human rights constitute themselves the basic foundation of the legal order. In the domain of the international law of human rights, moved by considerations of international ordre public, we are before common and superior values ${ }^{144}$ underlying it, and which appear truly fundamental and irreducible ${ }^{145} \mathrm{We}$ can here visualize a true droit au Droit, that is, the right to a legal order which effectively safeguards the rights inherent to the human person ${ }^{146}$ Of their faithful safeguard will depend, to a large extent, the future evolution of international law itself. This is the path to follow, for us and the following generations not to keep on living with the tragic contradictions which marked

${ }^{142}$ Cf. A A Cançado Trindade, A Humanização do Direito Internacional (Del Rey, 2006).

${ }^{143}$ On a ius commune of human rights at the international level, cf. M de Salvia, 'L'élaboration d'un jus commune des droits de l'homme et des libertés fondamentales dans la perspective de l'unité européenne: l'oeuvre accomplie par la Commission et la Cour Européennes des Droits de l'Homme,' in F Matscher and H Petzold (eds), Protection des droits de l'homme: la dimension européenne-Mélanges en l'honneur de G.J. Wiarda (C Heymanns Verlag, 1990), 555-63; G Cohen-Jonathan, 'Le rôle des principes généraux dans l'interprétation et l'application de la Convention Européenne des Droits de l'Homme,' Mélanges en hommage à L.E. Pettiti (Bruylant, 1998), at 168-9.

144 These values are perfectly identifiable, along the operative part of international treaties and instruments of human rights, but expressed above all in their preambles. These latter tend to invoke the ideals which inspired the respective treaties and instruments (of importance to the identification of their spirit), or to enunciate their foundations or general principles. Cf., in this respect, e.g., N Bobbio, 'Il Preambolo della Convenzione Europea dei Diritti dell'Uomo', (1974) 57 Rivista di Diritto Internazionale 437.

${ }^{145}$ Cf., in this sense, F Sudre, 'Existe t-il un ordre public européen?', in P Tavernier (ed), Quelle Europe pour les droits de l'homme? (Bruylant, 1996), at 41, 50, 54-67. For a classic study of the legal order, which sought to transcend pure normativism, cf. S Romano, L'ordre juridique (Dalloz, 2002).

${ }^{146}$ For a case-study in this respect, cf. A A Cançado Trindade et al, 'Gobernabilidad Democrática y Consolidación Institucional: El Control Internacional y Constitucional de los Interna Corporis-Informe de la Comisión de Juristas de la OEA para Nicarágua (Febrero de 1994)', (2000-2001) 67 Boleti $n$ de la Academia de Ciencias Politicas y Sociales-Caracas 593, at n. 137. 
the twentieth century.

\section{The Historical Significance of the International Subjectivity of the Individual}

The international juridical subjectivity of the human being, as foreseen by the so-called "founding fathers" of international law (the droit des gens), is nowadays a reality. At this beginning of the twenty-first century, this highly significant conquest can be appreciated within the framework of the historical process of humanization of international law, to which it is a privilege to be able to contribute, which, always attentive to fundamental values, comes to occupy itself more directly of the realization of superior common goals. In the ambit of the international law of human rights, in the European and inter-American systems of protection-endowed with international tribunals in operation-parallel to the legal personality, also the international procedural capacity (locus standi in judicio) of the individuals is acknowledged today.

This is a logical development, as it does not seem reasonable to conceive rights at the international level without the corresponding procedural capacity to vindicate them; the individuals are effectively the true complainant party in the international contentieux of human rights. On the basis of the right of individual petition is erected the juridical mechanism of emancipation of the human being vis-à-vis his own state for the protection of his rights in the ambit of the international law of human rights ${ }^{[17}$ an emancipation which constitutes, in our days, a true juridical revolution, which comes at last to give an ethical content to the norms of both domestic public law and international law.

The recognition of the direct access of the individuals to international justice reveals, at the beginning of the twenty-first century, the new primacy of the raison de l'humanité over the raison d'Etat, inspiring the historical process of humanization of international law ${ }^{148}$ The subjects of international law have,

\footnotetext{
${ }^{147}$ If the aforementioned right of petition had not been originally conceived and consistently understood in this way, the international protection of human rights would have advanced very little in slightly over half a century of evolution. With the consolidation of the right of individual petition before international tribunals-the European and Inter-American Courts-of human rights, it is the international protection that attains its maturity.

${ }^{148}$ A A Cançado Trindade, A Humanização do Direito Internacional, supra n. 142.
} 
already for a long time, ceased to be reduced to territorial entities ${ }^{149}$ Nowadays it appears quite clear that there is nothing intrinsic to international law that would impede, or render it impossible, for non-state actors to be endowed with international legal personality and capacity. Yet, part of the contemporary legal doctrine keeps on referring to individuals as actors (rather than subjects) in the international legal order. This is not a juridical term, it is rather a term of art, to which no specific juridical contents and consequences are necessarily attached. To call the individuals actors in international law is nothing but a platitude. They are true subjects of international law, bearers of rights and duties which emanate from international law.

No one in sane conscience would deny that individuals effectively possess rights and have duties which derive directly from international law, with which they thus are in direct contact. And it is perfectly possible to conceptualize as subject of international law, precisely, any person or entity, titulaire of rights and bearer of obligations, which emanate directly from norms of international law. It is the case of individuals, who have their direct contacts-without intermediaries-with the international legal order thus fostered and strengthened. This evolution is to be appreciated in a wider dimension. The expansion of international legal personality, nowadays encompassing that of individuals as active and passive subjects of international law, goes pari passu with the acknowledgment of accountability in international law.

This contributes ultimately to the international rule of law, to the realization of justice also at the international level, thus fulfilling a long-standing aspiration of humankind. In reaction to the successive atrocities which, along the twentieth century, have victimized millions and millions of human beings, in a scale until then unknown in the history of humankind, the universal juridical conscience, as the ultimate material source of all Law, has restored to the human being his condition of subject of both domestic and international law, and final addressee of all legal norms, of national as well as international origin. Human beings were to benefit from that, and international law itself was thereby enriched and justified. International law liberated itself from the chains of statism, and again met with the conception of a true, and new, ius gentium.

As the attentions of contemporary international legal doctrine on the

\footnotetext{
${ }^{149}$ More than half a century ago, as acknowledged in the celebrated Advisory Opinion of the International Court of Justice on Reparations for Injuries Suffered in the Service of the United Nations, ICJ Reports 1949, p. 174 1949, the advent of international organizations had put an end to the States' monopoly of the international legal personality and capacity, with all the juridical consequences which ensued therefrom, cf., for a general study on the matter, A A Cançado Trindade, Direito das Organizações Internacionais (Del Rey, 2012).
} 
expansion of the international legal personality turn to the central position occupied today by the victimized individuals, giving unequivocal witness of the new ius gentium of our times ${ }^{150}$ as I sought to demonstrate in the General Course of Public International Law which I delivered in 2005 at the Hague Academy of International Law ${ }^{151}$ the mechanical and thoughtless attachment to unfounded dogmas of the past becomes even more unsustainable. But as we do not live in a rational world, we ought to remain attentive to avoid an eventual contamination of nostalgia of immobility, even in our days (at a time when one reads less and less, and reflects less and less). Thus, as we enter the second decade of the twenty-first century, it appears truly surprising to find those who, in admitting the opening of international law to the expansion of the international legal personality (extending itself to individuals), notwithstanding insist, in a rather contradictory way, on the permanence of the traditional State-centric outlook, out of which they seem to feel lost.

Their position is indeed unsustainable: all they do is cling arbitrarily to the doctrinal developments of the nineteenth century, and try to project it-attempting to endow it with "perennial" validity-onto the present, making abstraction of the evolution of international law in more than a century. Yet, the state-centric world imagined by de Vattel ceased to exist a long time ago. The evolution of the law of nations, quite on the contrary, keeps on following its path in the twenty-first century, with the access to international justice nowadays secured also to persons who found themselves in situations of the utmost vulnerability, if not entirely in defencelessness (cf. supra).

Those who cling to a surpassed dogmatism, to the point of trying to make one believe that international law, "as we know it today", "began" in the nineteenth century, are simply distorting the truth. International law has much preceded the inter-state order established in the nineteenth with his historical roots going back to the thinking of its "founding fathers", the jusinternationalists of the sixteenth and seventheeth centuries, as recapitulated in the present keynote address. ${ }^{152}$. International law has much evolved since the nineteenth century, accompanying the profound transformations of the world,

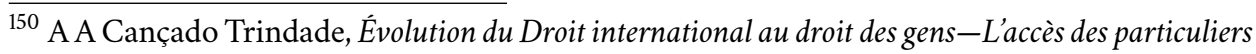
à la justice internationale: le regard d'un juge (Pédone, 2008), at 81-184; R Portmann, Legal Personality in International Law (Cambridge University Press, 2010), at 126-8, 243, 271-7, 283.

151 A A Cançado Trindade, 'International Law for Humankind: Towards a New Jus Gentium-General Course on Public International Law-Part I', (2005) 316 RCADI 252, at chs. IX-X.

${ }^{152}$ Cf. item II. 
and appearing today entirely distinct from what it then was ${ }^{153}$

In reaction to the succession of acts of barbarism and of the recurring horrors throughout the twenthieth century and the beginning of the twenty-first century, law cared to open itself to the expansion of the international legal personality, and, accordingly, of the corresponding legal capacity, as well as, significantly, of the international responsibility. Contemporary ius gentium has been undergoing a historical process of humanization ${ }^{154}$ caring to instrumentalize itself against the manifest insufficiencies and the dangers of the state-centric outlook or of the surpassed strictly inter-state vision. To that effect, the international law of human rights has much contributed, to the point of the phenomenon transcending the parameters of this latter, and permeating in our days the corpus iuris of international law as a whole.

Contemporary international case-law contains eloquent illustrations of the access of the human person to international justice in circumstances of considerable adversity, in cases pertaining to, e.g., undocumented migrants, children abandoned in the streets (cf. supra), members of peace communities and other civilians in situations of armed conflict, internally displaced persons, individuals (including minors of age) under infra-human conditions of detention, members of dispossessed indigenous communities, among others. In such circumstances, the centrality of the suffering of the victims has become notorious with their access to justice at the international level $[155$

Today, in such situations, effective use has been made of the international individual petition $\sqrt{156}$ something which could hardly have been anticipated, in their days, by the draftsmen of international treaties and instruments of human rights. On the other hand, such recent advances are not at all surprising, as the international law of human rights is essentially victim-oriented. Such development is due, in my perception, to the awakening of the human conscience to the imperative of protection of the human person in these circumstances of extreme vulnerability. It is in such circumstances that such protection reaches its plenitude.

${ }^{153}$ A A Cançado Trindade, O Direito Internacional em um Mundo em Transformação, supra n. 48, at 1039-1109.

${ }^{154}$ A A Cançado Trindade, supra n. 142, at 107-72.

155 Cf., on this particular point, A A Cançado Trindade, El Ejercicio de la Función Judicial Internacional-Memorias de la Corte Interamericana de Derechos Humanos (Del Rey, 2011), ch. XIX, at 159-65.

${ }^{156}$ Cf. A A Cançado Trindade, 'The Right of Access to Justice in the Inter-American System of Human Rights Protection', (2007) 17 Italian Yearbook of International Law 7; A A Cançado Trindade, 'Die Entwicklung des interamerikanischen Systems zum Schutz der Menschenrechte', (2010) 70 Zeitschrift für ausländisches öffentliches Recht und Völkerrecht 629. 
In effect, to this remarkable evolution I dedicate my recent book (of 2011), on the matter, published in Oxford ${ }^{[157}$ I examine therein some cases adjudicated by the IACtHR in recent years, a cycle of cases of massacres, with aggravating circumstances, wherein grave violations of human rights were planned and perpetrated in pursuance of state policies, forming a systematic practice of extermination of human beings. The adjudication of those cases was launched by the historic judgment of the IACtHR (of 14 March 2001) in the case of the massacre of Barrios Altos concerning Peru.

To that judgment followed the subsequent judgments of the IACtHR in the cases of the massacres of Caracazo concerning Venezuela (reparations, 29 August 2002)], of Plan de Sánchez pertaining to Guatemala (29 April 2004), of the 19 Tradesmen $v$ Colombia (5 July 2004), of Mapiripán v Colombia (17 September 2005), of the Moiwana Community ve Suriname (15 June 2005), of Pueblo Bello $v$ Colombia (31 January 2006), of Ituango v Colombia (1 July 2006), of Montero Aranguren and Others (Detention Centre of Cátia) v Venezuela (5 July 2006), of La Cantuta v Peru (29 November 2006), and of the Prison of Castro v Peru (25 November 2006), as well as in the cases of assassinations planned at the highest level of the state power and executed by order of this latter (such as that of Myrna Mack Chang (25 November 2003)).

Thus, massacres and crimes of state (perpetrated by state agents as part of a state policy), which tended to fall into oblivion some decades ago, have more recently been brought to the cognizance of international human rights tribunals (such as the Inter-American and European Courts), in order to determine the responsibility of the state (under the respective regional Conventions) for grave violations of the protected human rights ${ }^{158}$ Cases of the kind have also been lodged, to other effects, with other international tribunals, such as the international criminal ones (for the determination of individual international criminal responsibility), and the ICJ, in the framework of the inter-state contentieux.

Thus, more recently, within this latter, I have had the occasion to retake the consideration of the matter in my extensive Individual Opinions (two of them Dissenting, and one Separate), in distinct stages of the case pertaining to state immunities, opposing Germany to Italy before the ICJ (2010-2012). Thus, in my Separate Opinion in the case of the Jurisdictional Immunities of the State, in

${ }^{157}$ A A Cançado Trindade, The Access of Individuals to International Justice (Oxford University Press, 2011).

${ }^{158}$ For a recent study, cf. A A Cançado Trindade, State Responsibility in Cases of Massacres: Contemporary Advances in International Justice (Inaugural Address, 10 November 2011) (Universiteit Utrecht, 2011). 
supporting the intervention by Greece (Order of 4 July 2011), I cared to set forth, pedagogically, the distinct positions of states as well as individuals as titulaires of rights, in the framework of the cas despèce (paras 9-54).

I thus purported to make even clearer the point I had earlier made, in the same case, in my Dissenting Opinion, in supporting the counter-claim of Italy (Order of 6 July 2010), to the effect that states cannot waive claims as to rights which are not theirs, but of individuals. In my own words, states

cannot waive claims for reparation of serious breaches of rights that are not theirs, rights that are inherent to the human person. Any purported waiver to this effect runs against the international ordre public, is in breach of ius cogens. This broader outlook, in a higher scale of values, is in line with the vision of the so-called "founding fathers" of the law of nations (the droit des gens, the ius gentium), and with what I regard as the most lucid trend of contemporary international legal thinking.

One cannot build (and try to maintain) an international legal order over the suffering of human beings, over the silence of the innocent destined to oblivion. At the time of mass deportation of civilians, sent to forced labour along the two World Wars (in 1916-1918 and in 1943-1945) of the XXth century (and not only the II World War), everyone already knew that that was a wrongful act, an atrocity, a serious violation of human rights and of international humanitarian law, which came to be reckoned as amounting also to a war crime and a crime against humanity. Above the will stands conscience, which is, after all, what moves the Law ahead, as its ultimate material source, removing manifest injustice. (paras 178-179)

Still in the same case of the Jurisdictional Immunities of the State, in my subsequent Dissenting Opinion (merits, judgment of 3 February 2012), I sustained that:

Individuals subjected to forced labour in the German war industry (1943-1945), or the close relatives of those murdered in Distomo, Greece, or in Civitella, Italy, in 1944, during the II world war, or victimized by other State atrocities, are the titulaires (with their ayants-droits) of the corresponding right to reparation. Victims are the true bearers of rights, including the right to reparation, as generally recognized nowadays. (para. 246). 
I added that there can be no state immunities in face of delicta imperii, of international crimes in breach of ius cogens. (para. 184) In my perception, the State-centric distorted outlook yields in face of the imperatives of justice. (paras 161-171) The realization of justice is in itself a form of the reparation due to individual victims of grave violations of human rights and of international humanitarian law. (paras 282-287)

The current multiplicity of contemporary international tribunals (a reassuring phenomenon of our times) has by itself considerably increased the number of justiciables all over the world, fostering the access to international justice in our days, even in cases of the aforementioned gravity. New developments have in fact occurred lately in international legal procedures ${ }^{159}$ such as the ones pertaining to the determination of the aggravated international responsibility of the states concerned, and the identification of the victims in distinct stages of those procedures.

An aggravating circumstance lies in the intentionality of the damage (to reveal the coexistence of the objective responsibility with the responsibility on the basis of fault or culpa). Modern history is full of examples in which the intellectual and material authors of massacres sought to characterize their victims - not seldom innocent and defenceless-as "enemies" to be eliminated, and also of "dehumanizing them" by undue uses of language and through distorsions by means of neologisms and euphemisms before murdering them 160 In reaction to cruelties of the kind, one may attest, in the international adjudication of such cases, the centrality and expansion of the notion of (direct)

${ }^{159}$ Cf., in this respect, A A Cançado Trindade, 'Reflexiones sobre los Tribunales Internacionales Contemporáneos la Búsqueda de la Realización del Ideal de la Justicia Internacional,' in Cursos de Derecho Internacional y Relaciones Internacionales de Vitoria-Gasteiz / VitoriaGasteizko Nazioarteko Zuzenbidearen eta Nazioarteko Harremanen Ikastaroak (Universidad del Paí s Vasco, 2010), at 17; A A Cançado Trindade, 'Os Tribunais Internacionais Contemporâneos e a Busca da Realização do Ideal da Justiça Internacional', (2010) 57 Revista da Faculdade de Direito da Universidade Federal de Minas Gerais 37.

${ }^{160}$ For dramatic personal accounts, cf. P Levi, The Drowned and the Saved (Vintage, 1989); J Améry, At the Mind's Limits (Indiana Univ. Press, 1980). And cf. also the studies of B A Valentino, Final Solutions: Mass Killing and Genocide in the Twentieth Century (Cornell University Press, 2004), at 17, 49, 55, 57, 71, 235; Y Ternon, Guerres et génocides au XXe. Siècle (O Jacob, 2007), at 14-5, 81-3, 138, 191, 279, 376; G Bensoussan, Europe-Une passion génocidaire, (Mille et Une Nuits, 2006), at 53, 134, 220, 228-9; J A Berry and C P Berry (eds), Genocide in Rwanda-A Collective Memory (Harvard University Press, 1999), at 3-4, 28-9, 87; B Bruneteau, Le siècle des génocides (A Colin, 2004), at 41, 43, 222, 229; E Staub, The Roots of Evil-The Origins of Genocide and Other Group Violence (Cambridge University Press, 2005), at 29, 103, 121, 142, 227; R J Bernstein, El Mal Radical-Una Indagación Filosófica (Lilmod, 2005), at 110-1, 145, 290-1. 
victim, and the relevance of their right to reparation for the damages suffered. It is highly significant that, in our days, surviving victims of massacres, and relatives of fatal victims, have had access to international justice.

States themselves today recognize and realize that they can no longer dispose, as they wish, of the human beings who happen to be under their respective jurisdictions ${ }^{161}$ Their power of action is not unlimited, ought to be guided by the faithful observance of certain fundamental values ${ }^{162}$ and of the general principles of law ${ }^{163}$ They are to respond for their eventual damages to human beings under their respective jurisdictions, and to provide the reparations due to them ${ }^{164}$ States cannot even shield themselves behind the international criminal responsibility of the individuals who perpetrated international wrongs; the responsibility of the state always subsists 165 The responsibilities of ones and the others do not exclude each other, but rather complement each other. The new international legal order of our times has emerged from the human conscience-the universal juridical conscience, as the ultimate material source of all Law. The expansion of the international legal personality has taken place to the benefit of all subjects of law, including the individuals as subjects of international law.

\section{Epilogue, in the Inter-Generational Dialogue}

I could not conclude my keynote address in this Conference without turning back to its beginning, as to the importance of the inter-generational dialogue

${ }^{161}$ Cf. my Separate Opinion (paras 1-231) in the Advisory Opinion of the ICJ on the Declaration of Independence of Kosovo (22 July 2010).

162 Cf., e.g., S Glaser, 'La protection internationale des valeurs humaines', (1957) 60 Revue générale de Droit international public 211.

${ }^{163}$ Cf. my Dissenting Opinion (paras 1-214) in the case of the Application of the International Convention on the Elimination of All Forms of Racial Discrimination (Georgia v Russian Federation), Judgment of the ICJ of 1 April 2011; cf. also my Separate Opinion (paras 1-184) in the recent case of Questions Relating to the Obligation to Prosecute or Extradite (Belgium v Senegal), Judgment of the ICJ of 20 July 2012); and cf. my Separate Opinion (paras 1-118) in the Advisory Opinion of the ICJ on the Revision of a Judgment of the ILO Administrative Tribunal upon a Complaint Filed against IFAD (1 February 2012).

${ }^{164}$ Cf. my Separate Opinion (paras 1-101) in the case of A S Diallo (Guinea $v$ D R Congo), reparations, Judgment of the ICJ of 19 June 2012).

${ }^{165}$ Cf. my Dissenting Opinion (paras 1-316) in the case of the Jurisdictional Immunities of the State (Germany v Italy, with Greece intervening), Judgment of the ICJ of 3 February 2012). 
such as the one we undertake here in Cambridge today, on 19 May 2012. I trust it may look clear, to the young scholars in statu pupillaris of our discipline, that the law of nations, the droit des gens, has much evolved, ultimately moved by the universal juridical conscience, which stands well above the will of the states. Those who serve states tend to think too highly of themselves, and to attribute a key role in this evolution to strategic international litigation.

Hence their adherence to the unsatisfactory and dangerous inter-state framework, and to dogmas of the past, and their insistence on trying to prolong certain moments of legal history, without realizing that theirs is a static outlook of the law of nations. After all, their activity is one of means-to "win a case"-and not of ends. Those encapsulated in dogmatisms of the past tend to undermine advances achieved in the contemporary ius gentium, such as those pertaining to the consolidation of the international legal personality and the capacity of individuals, which they label, at best, as "not perfect". They are longing for an international legal order which no longer exists.

Theirs is a static outlook, centred on states, unpersuasive for its arbitrary points of reference. Such outlook attempts in vain to minimize the remarkable evolution of international law itself, as illustrated, e.g., by the historical recovery of the human person as subject of the law of nations. That surpassed inter-state outlook discloses a far too limited view which nostalgically insists on what they regard as the "perfect" international legal personality of states, a "perfectness" taken for granted, without demonstration. The heralds of that outlook tend to forget that states were created by human beings for their common good, and benefited from "personification" on the basis-ironically-of an analogy with that of human beings. It is about time that states do their part, to the benefit of human beings who created them for the common good.

Contemporary international law has been moved, in its advances, by the search for justice and for the prevalence of common superior values. It has purported to enable individuals to exercise their rights (by acknowledging their legitimatio ad causam) and peoples to live in peace with justice. The fact is that, nowadays, individuals, even in the most adverse circumstances, and in situations of defencelessness (as we have seen), have had access to international justice; this would have been simply unthinkable in the nineteenth century, or even some decades ago. The international legal order nowadays promptly reacts to situations of manifest injustice.

The young colleagues, in statu pupillaris, of our discipline, have provided me a memorable day, in taking the spontaneous initiative of opening a space in this Conference, which marks the launching of their Cambridge Journal of International and Comparative Law, for the presentation of my reflections 
developed in my most recent book, The Access of Individuals to International Justice, on a theme which coincides with that of this Conference. May I extend the expressions of my appreciation to my young colleagues for their openness of spirit, and for having, by their gesture, furthermore given me the opportunity, paraphrasing Jorge Luis Borges, of this encounter with myself, surrounded by the lawns of Cambridge.

Looking back in time, I can recognize myself, at an early stage of my path, in the old Squire Law Library, in the endless search for knowledge, undertaken with free thinking. This self-recognition brings me relief and satisfaction, and I sense it is today made possible as I have remained always faithful to my ideals of youth throughout the years of my journey. I trust my young colleagues assembled herein value likewise free thinking, and realize that we can hardly seek sensibly for knowledge within straight-jackets, and mechanically attached to dogmas of the past.

It is important, in order to cultivate the freedom of thinking, to stay outside the strict confines of institutionalized "schools of thought"; I feel satisfied not to belong, and never to have belonged, to any such "schools". We have indeed to move beyond them. We can give our modest contribution to the improvement of the human condition essentially as free thinkers, moved by our ideals, and remaining always attentive to fundamental human values, standing well above dogmas. Human conscience (the recta ratio), the universal juridical conscience, stands well above the will of States.

Cambridge, 19 May 2012.

A.A.C.T. 